\title{
Volcanic activity and gas emissions along the South Sandwich Arc
}

\author{
Emma J. Liu ${ }^{1}$ (D) $\cdot$ Kieran Wood $^{2} \cdot$ Alessandro Aiuppa $^{3} \cdot$ Gaetano Giudice $^{4} \cdot$ Marcello Bitetto $^{3} \cdot$ Tobias P. Fischer $^{5}$. \\ Brendan T. McCormick Kilbride ${ }^{6} \cdot$ Terry Plank $^{7} \cdot$ Tom Hart $^{8}$
}

Received: 14 July 2020 / Accepted: 15 October 2020 / Published online: 11 December 2020

(C) The Author(s) 2020

\begin{abstract}
The South Sandwich Volcanic Arc is one of the most remote and enigmatic arcs on Earth. Sporadic observations from rare cloudfree satellite images - and even rarer in situ reports — provide glimpses into a dynamic arc system characterised by persistent gas emissions and frequent eruptive activity. Our understanding of the state of volcanic activity along this arc is incomplete compared to arcs globally. To fill this gap, we present here detailed geological and volcanological observations made during an expedition to the South Sandwich Islands in January 2020. We report the first in situ measurements of gas chemistry, emission rate and carbon isotope composition from along the arc. We show that Mt. Michael on Saunders Island is a persistent source of gas emissions, releasing $145 \pm 59 \mathrm{t} \mathrm{day}^{-1} \mathrm{SO}_{2}$ in a plume characterised by a $\mathrm{CO}_{2} / \mathrm{SO}_{2}$ molar ratio of $1.8 \pm 0.2$. Combining this $\mathrm{CO}_{2} / \mathrm{SO}_{2}$ ratio with our independent $\mathrm{SO}_{2}$ emission rate measured near simultaneously, we derive $\mathrm{a}_{2}$ flux of $179 \pm 76 \mathrm{t}_{\text {day }}{ }^{-1}$. Outgassing from low temperature $\left(90-100{ }^{\circ} \mathrm{C}\right)$ fumaroles is pervasive at the active centres of Candlemas and Bellingshausen, with measured gas compositions indicative of interaction between magmatic fluids and hydrothermal systems. Carbon isotope measurements of dilute plume and fumarole gases from along the arc indicate a magmatic $\delta^{13} \mathrm{C}$ of $-4.5 \pm 2.0 \%$. Interpreted most simply, this result suggests a carbon source dominated by mantle-derived carbon. However, based on a carbon mass balance from sediment core ODP 701, we show that mixing between depleted upper mantle and a subduction component composed of sediment and altered crust is also permissible. We conclude that, although remote, the South Sandwich Volcanic Arc is an ideal tectonic setting in which to explore geochemical processes in a young, developing arc.
\end{abstract}

Keywords South Sandwich Volcanic Arc $\cdot$ Volcanic activity $\cdot$ Volcanic gas emissions

Editorial responsibility: A. Cannata

Emma J. Liu

emma.liu@ucl.ac.uk

1 Department of Earth Sciences, University College London, 5 Gower Place, London WC1E 6BS, UK

2 Department of Aerospace Engineering, University of Bristol, Bristol BS8 1TR, UK

3 Dipartimento di Scienze della Terra e del Mare, Università di Palermo, Palermo, Italy

4 Sezione di Catania, INGV, Catania, Italy

5 Department of Earth and Planetary Sciences, University of New Mexico, Albuquerque, NM, USA

6 Department of Earth and Environmental Sciences, University of Manchester, Williamson Building, Oxford Road, Manchester M13 9QQ, UK

7 Lamont-Doherty Earth Observatory, Columbia University, New York, USA

8 Department of Zoology, University of Oxford, South Parks Road, Oxford OX1 3SZ, UK

\section{Introduction}

Arc volcanoes dominate the global volcanic emissions budget, collectively releasing tens of teragrams of volatiles into the atmosphere each year that have regional and global impacts on air quality and climate (Fischer et al. 2019). For many arc systems, these fluxes are well studied by surface measurements and the subsurface processes controlling them are at least constrained, if not yet fully understood. However, the global inventory of volcanic emissions remains incomplete because we lack data from a few remote, but very active, arcs (Aiuppa et al. 2019). Many of these remote settings are also vulnerable ecological sites where the habitat, although often free from human interference, is impacted frequently by volcanic activity (Reynolds 1996; Roberts et al. 2017).

The volcanoes of the South Sandwich Volcanic Arc (SSVA) are a significant source of tephra to the South Atlantic (Ninkovich et al. 1964) and the Antarctic mainland (Smellie 1999; Basile et al. 2001) and yet their remote location in the Southern Ocean has meant that their eruptive processes 
remain enigmatic compared to other arcs globally. The relatively recent development of the SSVA over the past 10 million years has been closely linked with the formation of the Drake Passage (Barker 1995; Vanneste and Larter 2002; Leat et al. 2013, 2016), making this one of the youngest known volcanic arcs on Earth and therefore one of the most critical for understanding the early stages of arc geochemical evolution. Records of historical activity are relatively limited, with in situ observations contributed by only a few expeditions (e.g. Holdgate and Baker 1979; Smellie et al. 1998; Derrien et al. 2019). Much of the monitoring data collected over the past two decades derive from satellite remote sensing observations (Lachlan-Cope et al. 2001; Patrick et al. 2005; Patrick and Smellie 2013; Gray et al. 2019), and yet even these are restricted to rare, cloud-free images. Satellite observations reveal persistent passive outgassing at many of the SSVA volcanoes, punctuated by sporadic explosive emissions, suggesting that the arc could be a significant source of volatiles to our atmosphere. Petrological constraints on magmatic volatile contents are lacking, as are data on the composition and flux of emitted gases. Here, we present geological and volcanological observations made during an expedition to the South Sandwich Islands in January 2020. We report measurements of gas chemistry, emission rate and carbon isotope signature from along the SSVA. Together, these observations contribute to a comprehensive view of the 'state of the arc', providing a foundation for future targeted studies.

\section{Background}

\section{Tectonic and ecological significance}

The South Sandwich Volcanic Arc (SSVA) is situated on the leading edge of the South Sandwich microplate, bounded to the west by the East Scotia Ridge (ESR) back-arc spreading centre and to the east by the South Sandwich Trench (Fig. 1; Barker 1970; Larter et al. 2003). Seafloor magnetic anomalies record continuous W-E spreading at the ESR since at least $\sim 15 \mathrm{Ma}$, initially at a full spreading rate of $\sim 27 \mathrm{~mm}$ year $^{-1}$ until $\sim 1.7 \mathrm{Ma}$ when spreading accelerated to the current rate of $63-$ $71 \mathrm{~mm}$ year $^{-1}$ (Barker 1995; Livermore et al. 1997; Larter et al. 2003; Thomas et al. 2003). The SSVA is built largely on the oceanic crust that formed at the ESR 10 Ma (Barker 1995; Larter et al. 2003) and is consequently one of the youngest volcanic arcs active today. The crust beneath the SSVA is relatively thin at 16-20 km compared to arcs globally $(\sim 30 \mathrm{~km}$ on average), consistent with its young age and extensional regime due to back-arc spreading (e.g. Larter et al. 2003; Calvert 2011).

The southern end of the SSVA is bounded by the South Sandwich fracture zone, an active transform fault accommodating dextral motion between the Antarctic and South Sandwich plates (Barker 1995; Thomas et al. 2003; Giner-
Robles et al. 2009). At the northern end of the arc, focal mechanisms associated with enhanced seismicity suggest that the underthrust plate is being torn at depth to accommodate subduction (Brett 1977; Giner-Robles et al. 2009). Upper mantle seismic anisotropy from shear wave splitting reveals a strain field that describes westward mantle flow into the back-arc region from the north and south (Livermore et al. 1997; Müller 2001; Müller et al. 2008), consistent with the enriched Atlantic mantle signatures observed in erupted basalts from the northern- and southern-most segments of the ESR (Leat et al. 2004).

Magmatism along the SSVA is the expression of westward oceanic-oceanic subduction of the South American Plate beneath the South Sandwich microplate. Plate convergence is accommodated by subduction rates of $69 \pm 11 \mathrm{~mm}^{-1}$ year $^{-1}$ (north) to $71 \pm 10.8 \mathrm{~mm} \mathrm{year}^{-1}$ (south), associated with an eastward rollback of the trench (Thomas et al. 2003; Smalley et al. 2007). The age of subducted crust entering the trench from the South American plate varies from $\sim 83 \mathrm{Ma}$ in the north to $\sim 27 \mathrm{Ma}$ in the south (Barker 1995). Almost all of the sediment entering the trench is subducted, and a welldeveloped accretionary prism has not been established (Vanneste and Larter 2002). A sedimentary section from site 701 (Ocean Drilling Programme, ODP 701; Fig. 1) shows that the pelagic sediment north of the arc is carbon-poor overall (Ciesielski et al. 1988). From top to bottom, the pelagic sequence from ODP 701 exposes three main units: $\sim 245 \mathrm{~m}$ of diatomaceous ooze, with intervals of siliceous clay-rich muds and volcanic ash; $200 \mathrm{~m}$ of diatomrich clay/mud, with lesser volcanic ash; $30 \mathrm{~m}$ of indurated nannofossil chalk - of mid to late Eocene age - overlying amygdaloidal olivine basalt basement (Ciesielski et al. 1988; Vervoort et al. 2011). Sediment thicknesses are thinner immediately east of the arc $(\sim 200 \mathrm{~m}$ on average; Plank and Langmuir 1998). Dredge samples of oceanic crust from the South Sandwich Trench (Pearce et al. 2000) and the American-Antarctic Ridge to the east (Lawver and Dick 1983) are dominated by exposed ultramafic materialserpentinised peridotites, harzburgites, dunites and gabbros - typical of slow-spreading tectonic settings.

Erupted magma compositions range from basaltic to silicic and populate both tholeiitic and calk-alkaline trends; tholeiitic basalts are by far the most abundant (Baker 1978; Pearce et al. 1995). Overall, the SSVA is considered a type example of early subduction zone magmatism (Baker 1978). Trace element systematics suggest a variable, element-specific subduction component from altered oceanic crust (Pearce et al. $1995)$. Boron isotope compositions $\left(\delta^{11} \mathrm{~B}\right)$ for South Sandwich lavas are among the highest reported for mantlederived lavas, suggesting substantial subduction erosion of serpentinised forearc material (Tonarini et al. 2011). Rates of terrigenous erosion from the South Sandwich volcanoes and forearc are high, supplying large amounts of volcaniclastic 


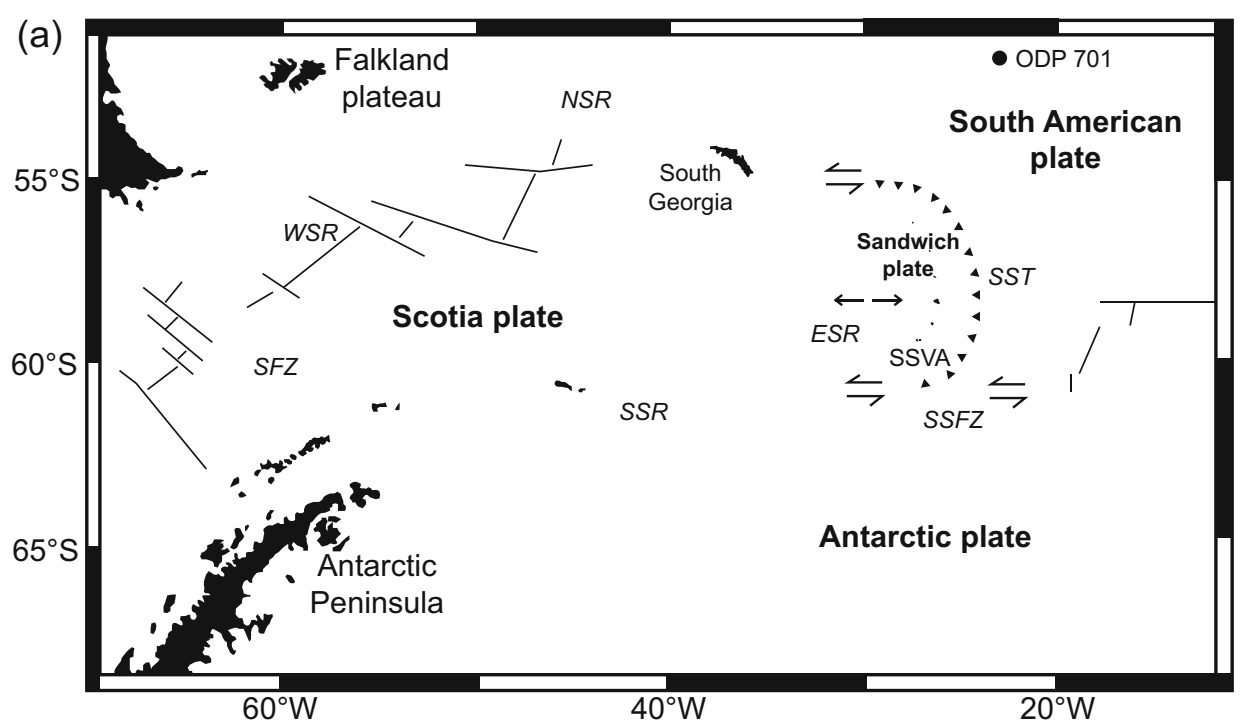

$60^{\circ} \mathrm{W}$

Fig. 1 Tectonic setting of the South Sandwich Islands volcanic arc (redrawn from Leat et al. 2016). a East Scotia Ridge (ESR), West Scotia Ridge (WSR), South Scotia Ridge (SSR), North Scotia Ridge (NSR), Shackleton Fracture Zone (SFZ), South Sandwich Trench (SST), South Sandwich Fracture Zone (SSFZ) and South Sandwich

material eastwards towards the trench (Leat et al. 2010; Tonarini et al. 2011). Overall, the carbon-poor nature of the sediments entering the trench lead to low predicted $\mathrm{CO}_{2} / \mathrm{SO}_{2}$ ratios $\sim 1.2$ in the corresponding arc emissions based on trace element proxies (Aiuppa et al. 2019).

The South Sandwich Islands (SSI) represent the emergent portions of deep-rooted volcanic edifices that comprise the arc front and extend to depths of 2000-3000 m below the seafloor (Leat et al. 2010, 2013, 2016). From north to south along the arc, the volcanic centres include Protector Seamounts (submerged), Zavodovski, Visokoi, Candlemas group (Candlemas and Vindication), Saunders, Montagu, Bristol, Southern Thule group (Bellingshausen, Cook and Thule) and Kemp and Adventure calderas (submerged). Since 1900, expressions of active volcanism (ranging from sporadic fumaroles to explosive eruptions) have been reported from all but Vindication, which represents the eroded remnants of an ancient stratovolcano. Volcanic edifices are constructed from layers of pyroclastic material and lavas (Baker 1978; Holdgate and Baker 1979; Smellie et al. 1998; Leat et al. 2003). Bathymetric surveys reveal numerous mass flow deposits associated with the submarine flanks of the SSI volcanoes (Leat et al. 2010, 2013). Active seafloor hydrothermal venting, important for sustaining chemosynthetic communities, has been reported from Kemp and Adventure calderas in the southern section of the arc and from the Protector Seamount region in the north (Boschen et al. 2013; Linse et al. 2019). The SSI are located south of the Antarctic Circumpolar Current and the topographic profile of the arc strongly influences the path of oceanographic currents (Garabato et al. 2002).
Volcanic Arc (SSVA). Location of the ODP site 701 (Leg 114) sediment core (Ciesielski et al. 1988). b Magnified view of the SSVA showing subaerial islands. Topographic data extracted from WorldDEM ${ }^{\mathrm{TM}}$ (Airbus Space and Defence)

The South Sandwich Islands have a polar climate, with heavy snowfall in winter and frequent strong winds and storm swells year-round. Terrestrial flora is scarce, dominated by mosses and lichens (Convey et al. 2000; Hart and Convey 2018). However, the islands are breeding grounds for globally significant populations of seabirds, notably penguins (Hart and Convey 2018). At the most recent census in 2011, the SSI contain almost half of the world's population of Chinstrap penguins (Lynch et al. 2016); 600,000 pairs are reported from Zavodovski Island alone, together with a further $\sim 95,000$ pairs of Macaroni penguins, and $>125,000$ pairs of Adelie penguins. The islands are administered as a UK Overseas Territory by the Government of South Georgia and the South Sandwich Islands. In response to calls for long-term management of the fishery and dependent wildlife, South Georgia and SSI were declared a Marine Protected Area in 2012, which was further expanded in 2019 (Marine Protected Areas Order 2013, 2019). Recent volcanic eruptions in the SSI are likely to have had significant and ongoing impacts on local terrestrial and marine ecosystems, through immediate disturbance, deposition of pyroclastic material (mostly as volcanic ash) and from persistent passive degassing. Historic volcanic eruptions elsewhere in the Antarctic have caused mass mortality in penguin colonies (Roberts et al. 2017).

\section{Methods}

We report on the state of current volcanic activity along the South Sandwich Volcanic Arc, with an emphasis on active outgassing. These observations were made during a 5-week 
expedition to South Georgia and the South Sandwich Islands in January 2020 aboard the Pelagic Australis. We sailed from Stanley, Falkland Islands, on 30 December 2019 and returned to the harbour on 30 January 2020. We made shore landings by zodiac on Saunders Island on three consecutive days between 6 and 8 January; Thule Island on 10 January; Bellingshausen on 11 January and Candlemas on 12 and 13 January. Aerial images of Zavodovski, Candlemas, Saunders, Bristol and Bellingshausen were acquired using a small Unoccupied Aerial System (UAS; DJI Mavic 2 Pro) and used to aid geological interpretation. Aerial gas measurements (see instrument specification below; Liu et al. 2019; Pering et al. 2020) were acquired using a multi-rotor UAS (DJI Matrice 200 modified with custom mounting platform). Full permissions for beyond visual line of sight UAS flights were obtained from the Government of South Georgia and the South Sandwich Islands under Air Navigation (Overseas Territories) Order 2013.

A summary of all sampling sites - including coordinates, distance from vent and access descriptions - are presented in Table S1 (supplementary information). All altitudes reported in the text are extracted from the WorldDEM ${ }^{\mathrm{TM}}$ topographic model, which has a relative vertical accuracy of $2 \mathrm{~m} \mathrm{(4} \mathrm{m}$ absolute) in a $12 \mathrm{~m} \times 12 \mathrm{~m}$ raster (C) DLR e.V. 2019 and (C) Airbus Defence and Space $\mathrm{GmbH}$ 2019). Images and videos were taken both on- and offshore and used for geological interpretation. A landing on Zavodovski was unfortunately not possible due to inclement weather and ocean conditions, instead, we report large-scale stratigraphic observations made from offshore and at outcrop-scale using a UAS launched from the boat (see Video, S1-S2, supplementary information). On Candlemas, we landed ashore by zodiac in Kraken Cove (in the north of the island; Fig. 2) before hiking to the peninsula of Lucifer Hills $(\sim 1 \mathrm{~h})$. Travel was slow, but not technical, over a'a lava flows. We acquired gas samples and measurements at the summit of Lucifer Hills (see methods below) and made outcrop-scale observations of the lavas as we traversed the peninsula, which were aided by aerial imagery acquired using a UAS launched from offshore. On Saunders, we landed ashore by zodiac at the southern end of Cordelia Bay (eastern side of the island; Fig. 2). We walked to the centre of the bay before ascending onto the glacier on the eastern flank of Mt. Michael, contouring around to reach sampling sites on the northeastern and southern sides of the volcano (2-3 h one way). Access involved technical glacier travel across heavily crevassed terrain. We made in situ observations of recent pyroclastic deposits exposed on and within the glacier, together with stratigraphic observations of the layered hydromagmatic deposits exposed on the eastern flank of Ashen Hills (Fig. 2). Large-scale observations of the topography and the plume were aided by a UAS launched from Natriss Point (Video S3, supplementary information). On Bellingshausen, access involved a challenging shore landing near Isaacson Point (southern side of the island; Fig. 2). There are few sheltered landing sites for a zodiac due to steeply eroded cliffs and none during a heavy swell. We swam ashore from a zodiac positioned several tens of metres offshore, wearing a full dry suit and buoyancy aid, and then hauled equipment ashore in sealed dry bags attached to a rope line. From the coast, the hike to the crater rim (30 min one way) was straightforward over relatively smooth terrain (eroded and vegetated lava flows). From the southern rim of the crater, we descended a steep but not technical scree slope to the base of the crater where several fumaroles are located. We made in situ observations of the large-scale stratigraphy of the crater from the crater rim, supplemented by aerial imagery from a UAS launched from the boat (Video S4, supplementary information). We made outcrop-scale observations of layered pyroclastic deposits and massive lava flows at Hardy Point. At Thule, we landed ashore by zodiac at the ice-free Hewison Point (southeastern tip of the island; Fig. 2), acquiring outcrop-scale observations of the exposed lava flows and layered pyroclastic deposits.

Fumarole temperatures were measured using a K-type thermocouple that was calibrated immediately prior to the field campaign. Gas compositions were measured using two versions of a multi-component gas analyser system (Multi-GAS; Aiuppa et al. 2005; Shinohara 2005): ground-based and dronemounted. The plume was sampled through two 1- $\mu \mathrm{m}$ particle filters exposed to ambient air, at a pump rate of $1.0 \mathrm{~L} / \mathrm{min}$. Concentrations of $\mathrm{CO}_{2}, \mathrm{SO}_{2}$ and $\mathrm{H}_{2} \mathrm{~S}$ were logged at $1 \mathrm{~Hz}$. For the ground-based Multi-GAS, $\mathrm{SO}_{2}, \mathrm{H}_{2} \mathrm{~S}$ and $\mathrm{H}_{2}$ electrochemical sensors (3ST/F-TD2G-1A, T3H-TC4E-1A and T3HYT-TE1G-1A, City Technology) were calibrated for 0-200, 0-100 and 0-200 ppmv, respectively, each with an accuracy of $\pm 2 \%$ and a resolution of 0.1 ppmv. A nondispersive infrared (NDIR) spectrometer (GasCard NG, Edinburgh Instruments) was calibrated for 0-3000 ppmv $\mathrm{CO}_{2}$ with an accuracy of $\pm 2 \%$ and a resolution of $0.8 \mathrm{ppmv}$. Pressure $( \pm 1 \mathrm{hPa})$, temperature $\left( \pm 0.5^{\circ} \mathrm{C}\right)$ and relative humidity $( \pm 2 \%)$ were also measured at $1 \mathrm{~Hz}$ (Galltec sensors). For the aerial Multi-GAS, $\mathrm{SO}_{2}$ and $\mathrm{H}_{2} \mathrm{~S}$ electrochemical sensors (3ST/F-TD2G-1A and T3H-TC4E-1A, City Technology) were calibrated for 0-200 and 0-50 ppmv, respectively, each with an accuracy of $\pm 2 \%$ and a resolution of 0.1 ppmv. A NDIR spectrometer (Smartgas Modul Premium2, Microsensorik) was calibrated for 0-5000 ppmv $\mathrm{CO}_{2}$ with an accuracy of $\pm 2 \%$ and a resolution of $1 \mathrm{ppmv}$. The unit was shielded from radio frequency interference from the UAS transmission system using a foil wrapping. Pressure $( \pm 1 \mathrm{hPa})$, temperature $\left( \pm 0.5^{\circ} \mathrm{C}\right)$ and relative humidity $( \pm 3 \%)$ were also measured at $1 \mathrm{~Hz}$ using a combined sensor module (Bluedot BME280) exposed to ambient air. Both Multi-GAS instruments were calibrated with standard reference gases at the Università di Palermo (Palermo, Italy) immediately prior to the field campaign. All sensor data was logged to a micro-SD card. $\mathrm{H}_{2} \mathrm{O}$ concentrations were calculated from 

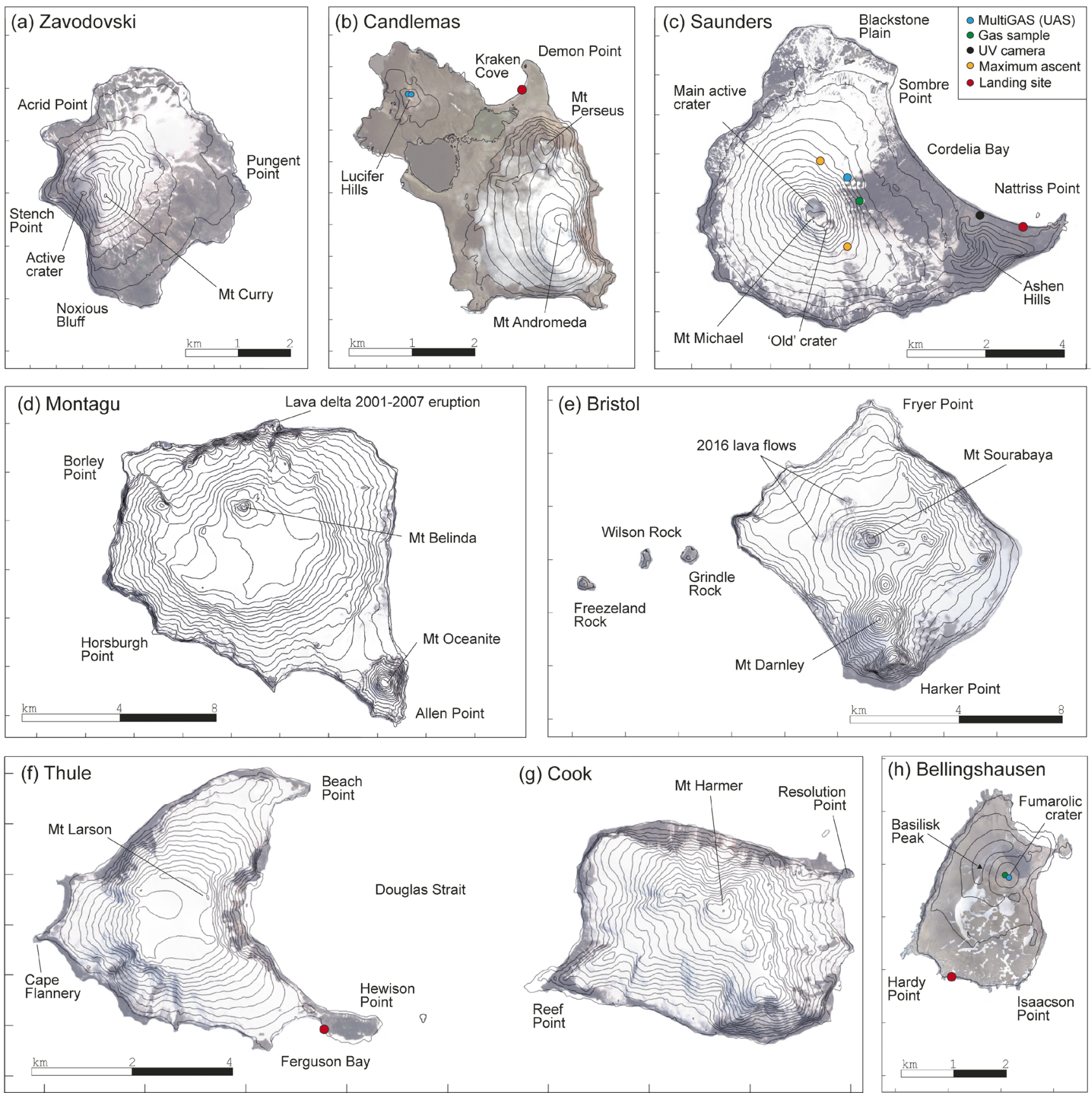

Fig. 2 Detailed location maps for the South Sandwich Islands (to scale). Key locations discussed in the main text, such as landing and sampling sites, are annotated with coloured circular symbols according to the legend in c. Elevation contours at $50 \mathrm{~m}$ are extracted from WorldDEM DTM $^{\mathrm{TM}}$ (@ DLR e.V. 2019 and (C) Airbus Defence and Space GmbH 2019). Background images are $\mathbf{a}-\mathbf{g}$ Copernicus Sentinel-2 satellite

imagery (European Space Agency) acquired on 2 December 2019 (Montagu), 5 December 2019 (Zavadovski) or 24 December 2019 (all others islands); and $\mathbf{h}$ orthorectified image generated from unoccupied aerial system imagery acquired on 10 January 2020 using Agisoft Metashape Professional (version 1.6.3)

records of temperature, relative humidity and timeaveraged ambient pressure (according to the Arden Buck equations relating the pressure of vapour saturation to temperature for moist air; Buck 1981). Time series of gas concentrations were post-processed using Ratiocalc software (Tamburello 2015). Volcanogenic $\mathrm{CO}_{2}$ and $\mathrm{H}_{2} \mathrm{O}$ were resolved from the atmospheric background by subtracting

the $\mathrm{CO}_{2}$ and $\mathrm{H}_{2} \mathrm{O}$ in ambient air (measured outside the plume where $\mathrm{SO}_{2}=0$ ) from the raw $\mathrm{CO}_{2}$ time series. $\mathrm{H}_{2} \mathrm{~S}$ concentrations were corrected for the $13 \%$ cross-sensitivity of the sensor to $\mathrm{SO}_{2}$ (determined during calibration with standard reference gases). For example, although the absolute detection limit of the $\mathrm{H}_{2} \mathrm{~S}$ sensor is $0.1 \mathrm{ppm}$, the effective detection limit is $0.13 \times \mathrm{SO}_{2} \mathrm{ppm}$. 
Molar gas ratios are derived from the gradient of the linear regression in two-species scatterplots, with the exception of $\mathrm{H}_{2} \mathrm{O}$. Uncertainties are reported as the $95 \%$ confidence intervals on the regression. The relative humidity sensor reached saturation very quickly during fumarole measurements at Bellingshausen and Candlemas, and therefore, derived $\mathrm{H}_{2} \mathrm{O}$ concentrations are of lower quality. $\mathrm{H}_{2} \mathrm{O} / \mathrm{X}$ ratios, where $\mathrm{X}$ is the gas species used as the plume marker, were estimated assuming a simple step change in concentration $\left(\frac{\left(\mathrm{H}_{2} \mathrm{O}_{\max }-\mathrm{H}_{2} \mathrm{O}_{\text {background }}\right)}{\left(\mathrm{X}_{\max }-\mathrm{X}_{\text {background }}\right)}\right)$. Due to sensor saturation, derived $\mathrm{H}_{2} \mathrm{O} / \mathrm{X}$ ratios underestimate the true ratio and will be highly uncertain; we estimate a $50 \%$ uncertainty on these values to be conservative, although it is difficult to quantify the error explicitly.

The emission rate, or flux, of $\mathrm{SO}_{2}$ was determined spectroscopically using a dual UV imaging camera developed at Università di Palermo (Palermo, Italy) and described in Delle Donne et al. (2017, 2019). The instrument, powered by a lithium-polymer battery, was equipped with two JAI CM140GE-UV cameras sensible to UV radiation and fitted with two distinct bandpass optical filters (both of $10 \mathrm{~nm}$ full width at half-maximum) with central wavelengths of 310 (strong $\mathrm{SO}_{2}$ absorption) and $330 \mathrm{~nm}$ (weak $\mathrm{SO}_{2}$ absorption). A separate computer was used to command and control operations and to save the acquired images. We deployed the UV camera on Saunders on 8 January 2020 , operating (at $0.5 \mathrm{~Hz}$ rate) from 13:50 to $16: 40$ UTC. During this time interval, the plume was dispersing to the east with the prevailing winds. The plume was grounding down the eastern flank, before lifting off and being transported at an altitude of several hundred metres above sea level.

The acquired images $(520 \times 676$ pixels at 10 -bit resolution $)$ were post-processed using standard techniques (Kern et al. 2015; Delle Donne et al. 2017, 2019). Sets of co-acquired images were first combined to obtain sequences of "absorbance" images and then converted into slant column densities using calibrations derived from $\mathrm{SO}_{2}$ reference cells (uncertainty, $\pm 10 \%)$. Finally, a time series of integrated column densities were obtained for each dataset by integrating the sequences of slant column densities images along a crosssection perpendicular to plume transport. Multiplication of the integrated column density by the plume speed yielded the $\mathrm{SO}_{2}$ flux time series. Plume speeds (uncertainty, $\pm 5 \%$ ) were derived using the optical flow algorithm of Lucas and Kanade (1981) to track the motion of plume gas fronts in image sequences (Delle Donne et al. 2017, 2019). Light dilution was corrected for using the method of Campion et al. (2015) and found to be negligible. In-plume, multiple scattering effects associated with the highly condensed plume are significant and mean that our derived slant column densities almost certainly underestimate the true column density; this is not modelled explicitly, however.
Dilute gas samples for carbon isotope measurements were collected in foil bags using a pumped inlet system operating for $90 \mathrm{~s}$. Two bag samples were collected in the downwind plume from Mt. Michael, Saunders, and a further two from strong fumarolic emissions within the crater on Bellingshausen. A clean ocean air sample was collected several miles offshore from the Falkland Islands, with the boat engine turned off. Gas samples were analysed for their $\mathrm{CO}_{2}$ concentration and carbon isotope composition (expressed as $\delta^{13} \mathrm{C}[\%$ o]) by Delta Ray Infrared Isotope Ratio Spectrometer (Fischer and Lopez 2016; Ilanko et al. 2019) at the University of New Mexico (Albuquerque, USA). One sample was collected at a temperature of $96^{\circ} \mathrm{C}$ from a vent on Lucifer Hills, Candlemas, using a preevacuated Giggenbach bottle. The bottles did not contain $\mathrm{NaOH}$ solution due to the challenges of transporting caustic solution to these pristine islands. The bottle was connected via silicone tubing to a titanium tube and inserted into the vent. The sample was analysed in the Volatiles Lab at the University of New Mexico utilizing a combination of gas chromatography with a discharge ionization detector and quadrupole mass spectrometry following the techniques described in Ilanko et al. (2019).

\section{Results and discussion}

\section{Protector Seamounts}

Protector Seamounts represent the northernmost volcanic region of the SSVA. A submarine eruption of rhyolite lava took place at Protector Shoal-a shallow cone within $55 \mathrm{~m}$ of the sea surface - in 1962 (Gass et al. 1963). The eruption produced an extensive pumice raft that was encountered by HMS Protector in the vicinity of Zavodovski island soon after (Gass et al. 1963) and as far as New Zealand over the following years (Coombs and Landis 1966). No observations were made during this expedition.

\section{Mt. Curry, Zavodovski}

Zavodovski hosts a single volcanic edifice, Mt. Curry (also known as Mt. Asphyxia; $557 \mathrm{~m}$ asl), surrounded by an extensive lava platform to the east (Fig. 2). Volcanic activity is focused at a steeply inclined crater on the southwest flank of Mt. Curry (Patrick and Smellie 2013). Vigorous vapour emissions were first reported in 1819 and similar observations have been reported since, notably in 1830 when emplacement of a fresh "pumiceous" lava flow was also documented on the eastern flank (Holdgate and Baker 1979). Most recently, ash-rich plumes were observed emanating from the main crater between March and June 2016, covering the eastern flanks in fresh dark ash deposits; large bombs were reportedly ejected from the crater (GVP 2017a). 
The broad, low-lying lava platform on the eastern side of the island has undulating topography with deeply incised water gulleys. Two pyroclastic cones are visible on the lower flanks of Mt. Curry, one of which appears to be constructed from two coalesced explosion craters (Fig. 3d). Columnar jointing is exposed at the base of the eastern margins of the lava platform (Fig. 3f). This quasi-hexagonal fracture geometry forms due to thermal contraction of lava driven by conductive cooling, often associated with water infiltration into fractures (e.g. Spry 1962; Phillips et al. 2013; Lamur et al. 2018; Li and Liu 2020). Here, straight and uniform columnar fractures - colonnade jointing - are present in the dense lower part of the lava flow, suggesting enhanced cooling gradients as the flow entered the sea. The lack of jointing in the overlying rubbly flow unit indicates that the upper part of the flow was insulated to some degree. A thin layer of pyroclastic deposits appears to mantle the top surface of the lava flows in many of the eroded cross-sections.

Intense outgassing was visible on the western side of the island, originating from the main crater (Fig. 3a) -located on the inclined western flank of Mt. Curry - and also from fumaroles within the steeply eroded cliffs below. The base of the crater was obscured by dense, condensed emissions (Video $\mathrm{S} 1$, supplementary information), presumably rich in water vapour. The rim of the crater is precipitously thin, with vertical inside walls. The lower left rim of the crater is heavily fractured and encrusted in yellow sulfurous deposits from the pervasive fumaroles (Fig. 3a). Dispersed fumarolic emissions are visible in the exposed cliffs and are particularly prevalent at the base of the cliff directly beneath the main crater.

The local stratigraphy is well exposed in the cliffs between Acrid Point and Noxious Bluff, passing Stench Point (Fig. 4; Video S2, supplementary information). The rocks are vibrant shades of red through yellow, indicative of intense oxidative and hydrothermal weathering. At the base of the sequence, a series of relatively thin lava flows are interbedded with thin pyroclastic units. Thick lava flow units with minor pyroclastic intervals characterise the middle part of the stratigraphy. Thick pyroclastic units cap the upper part of the sequence, with a sharp contact with the underlying flow units. Pyroclastic deposits are horizontally layered and mantle the topography of underlying units. The stratigraphic transition from basal lava flows with minor pyroclastic intervals to dominantly pyroclastic emission suggests a general evolution from effusive cone-building activity to more explosive activity through time. A layered pyroclastic deposit mantles the topography, suggesting deposition as ashfall and is particularly well preserved on Stench Point (Fig. 4c, f). Vertical dyke-like structures are visible in the stratigraphy, standing proud by resistance to erosion; however, it is unclear where they originate or terminate (Fig. 4b, e). The ubiquitous dense, angular bombs scattered over Stench Point (Video S2, supplementary information) represent ballistic projectiles emitted from the main crater during periods of enhanced explosive activity, most likely in 2016.

\section{Lucifer Hills, Candlemas}

Candlemas is dominated by the imposing forms of two steeply eroded stratovolcanoes, Mt. Perseus and Mt. Andromeda (557 m asl; Fig. 2), both extensively glaciated. Steep cliffs beneath the ice cap expose a thick stratigraphy of alternating lava flows and pyroclastic units (Fig. 5b). Historically, active volcanism is been focused at the Lucifer Hills Complex, a series of coalesced cinder cones in the northeast region of the island (140 m asl; Fig. 5d-e). Here, andesitic-dacitic extrusive activity has built a radial promontory composed of multiple overlapping lava flow units of unknown age. Dark brown clouds emanating from Lucifer Hills were observed in 1823 and 1911, possibly in association with lava extrusion (LeMasurier et al. 1990). Steam emissions have been repeatedly reported from abundant fumaroles, most recently in 2006 (Patrick and Smellie 2013). Geothermal activity in the form of geysers and hot pools was reported by LeMasurier et al. (1990) but was no longer visible by 1997. Satellite observations between 2000 and 2010 detected a persistent thermal anomaly centred on Lucifer Hills (Patrick and Smellie 2013).

The peninsula is composed of silicic lava flows (andesite to dacite; Baker 1978; Pearce et al. 1995) that have built an extension to the main island landmass. The lava flows are arranged in overlapping lobes that protrude out into the sea. The flows originate from small scoria cones within the main Lucifer Hills complex and can generally be traced back to breaches of the cone wall (Fig. 5f). The flows are generally thick and brecciated and have not travelled far from their source vents. Aerial views show radiating surface ridges (Fig. 5f) resembling those reported in silicic lava flows at Cordon-Caulle (Farquharson et al. 2015). Surface ridges are compressional features formed in response to flow under a cross-sectional viscosity gradient (between the cooled crust and the hot, fluid lava beneath; Fink 1980).

Outgassing activity is currently focused around the rim of the summit crater, with a further region of diffuse steaming ground located on the upper western flank of the edifice. We sampled the summit crater emissions in two places: first at a fumarole on the inside of the eastern rim and then at another on the southwestern rim (annotated on Fig. 5d and described in Table S1, supplementary information). The two measurement sites showed contrasting gas compositions, as measured by Multi-GAS (Fig. 6; Table 1). We detected substantial excess $\mathrm{CO}_{2}$ concentrations up to $2134 \mathrm{ppm}$ (after subtraction of an atmospheric background concentration of $407 \mathrm{ppm}$ ) at the first fumarole site CM-1, but no sulfur species. Gas temperatures at the point of emission ranged from 88 to $97{ }^{\circ} \mathrm{C}$ but varied by less than $2{ }^{\circ} \mathrm{C}$ during repeat measurements at each fumarole. The second fumarole site $\mathrm{CM}-2$, in contrast, was encrusted by conspicuous yellow sulfur deposits and its emissions contained detectable $\mathrm{SO}_{2}$ and $\mathrm{H}_{2} \mathrm{~S}$ (in the proportion $\mathrm{H}_{2} \mathrm{~S} / \mathrm{SO}_{2}=25.6 \pm 2.2$ ), together with excess $\mathrm{CO}_{2}$ 

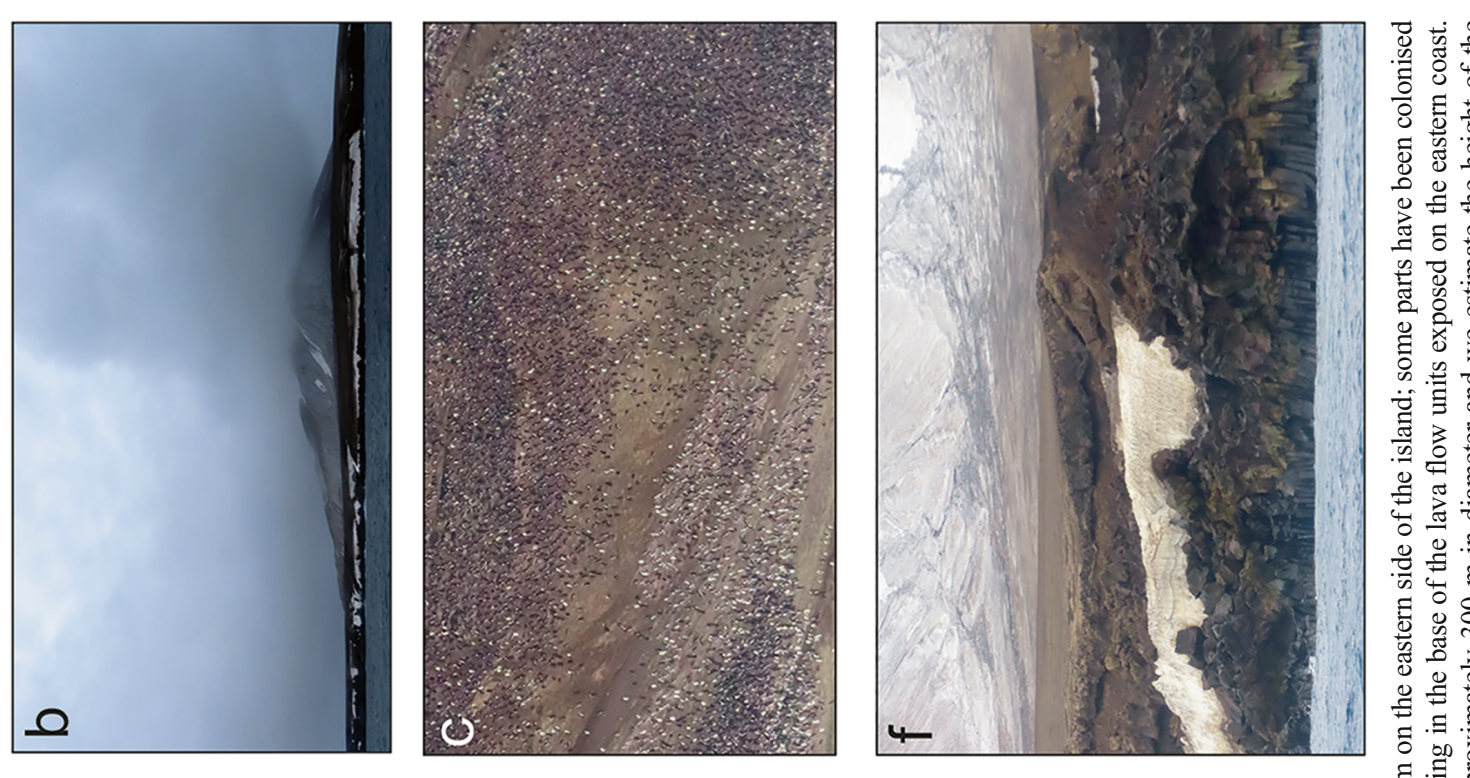

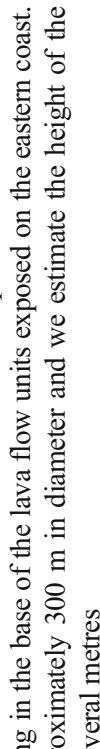

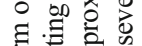
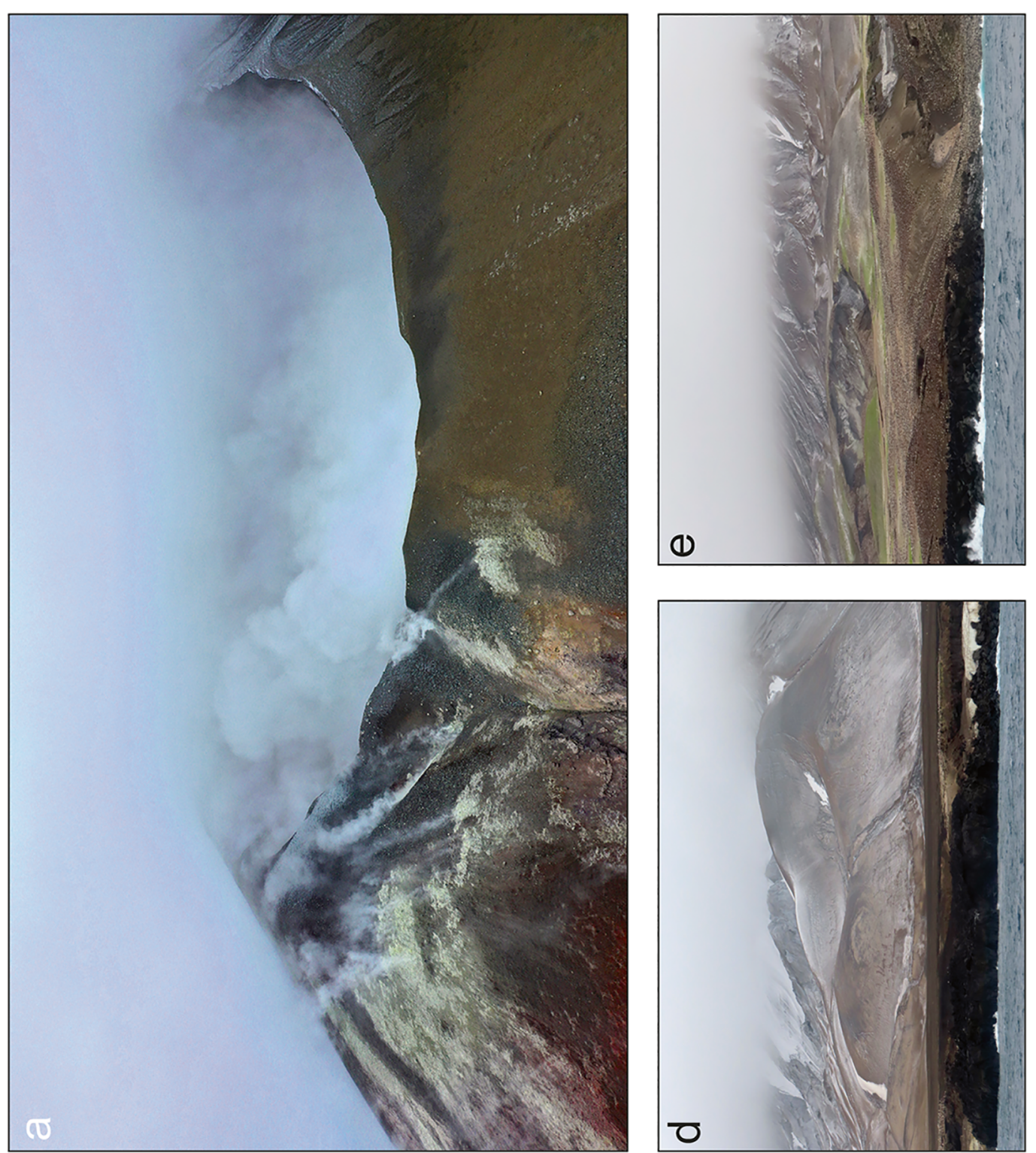

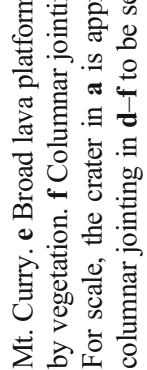

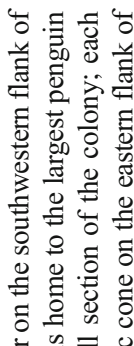

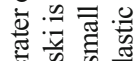

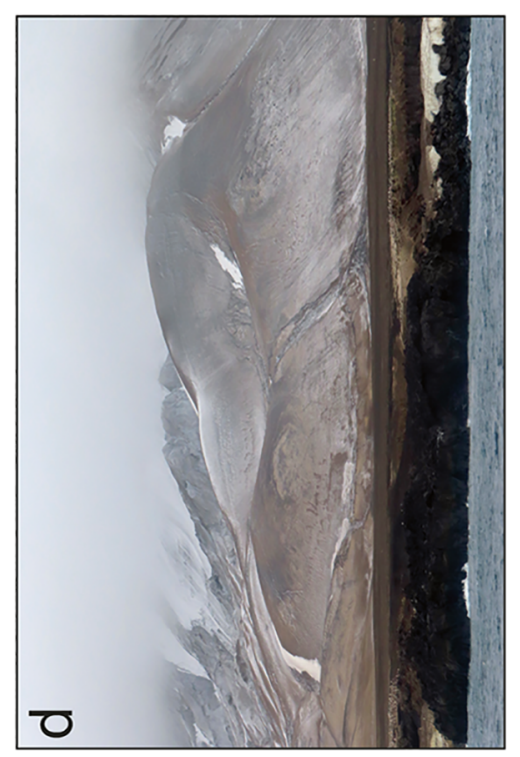

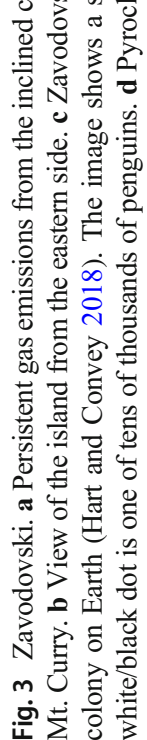



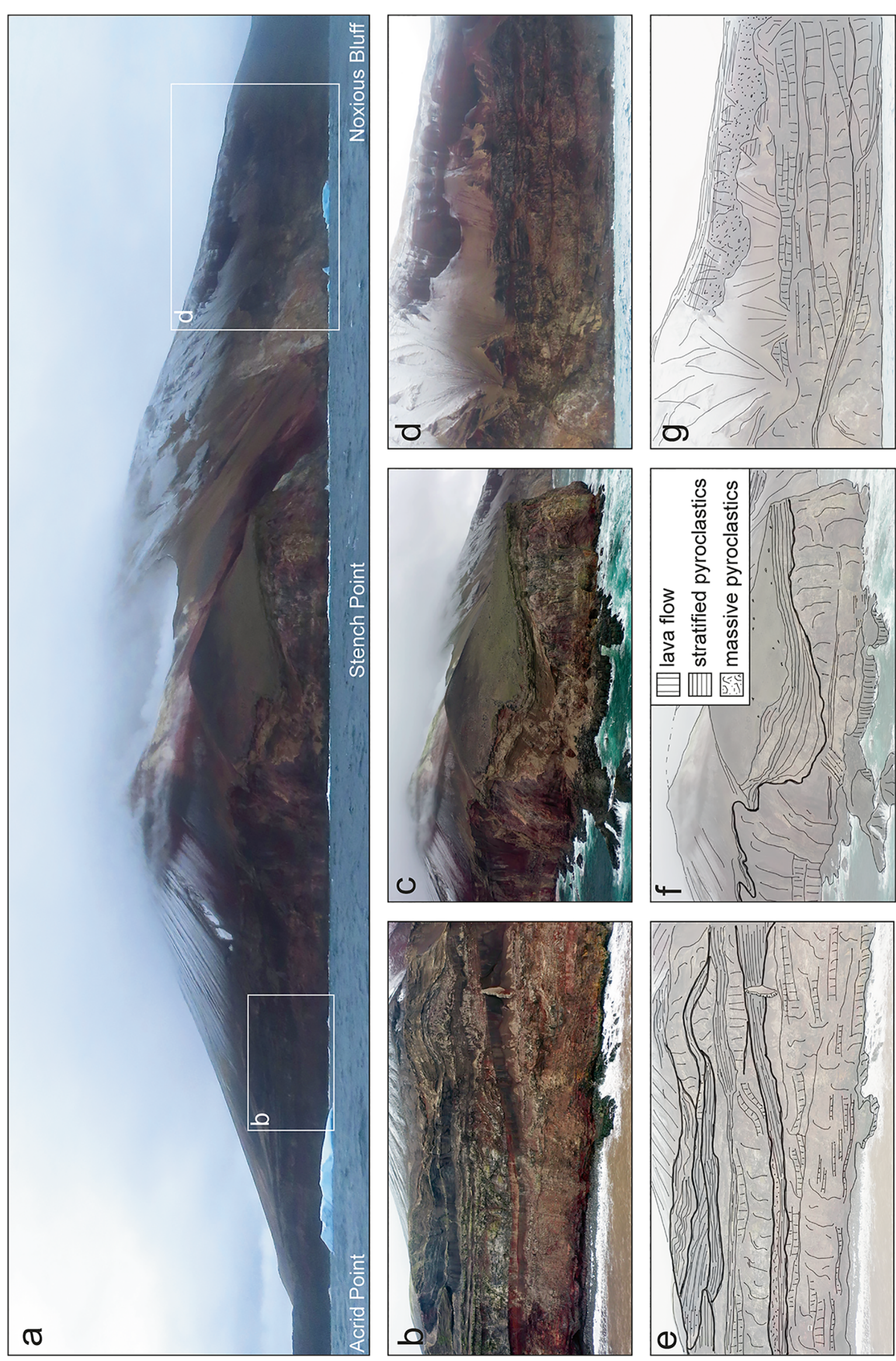

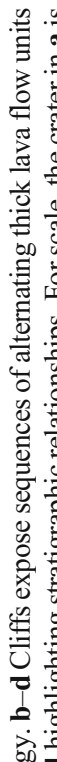
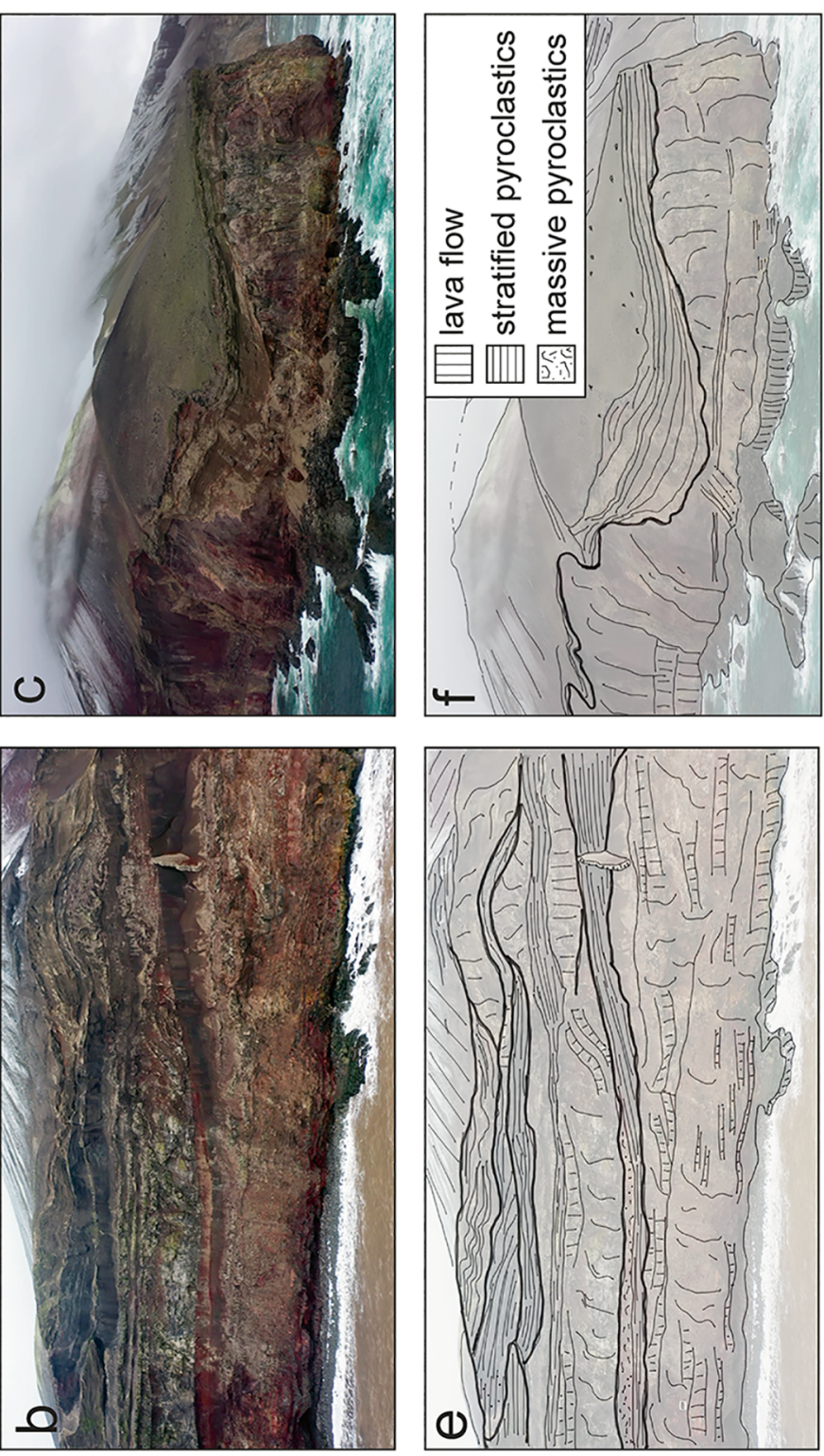

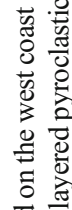

흥

这

o

음

胥

O

要

윰 충

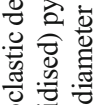

客望

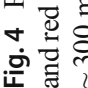



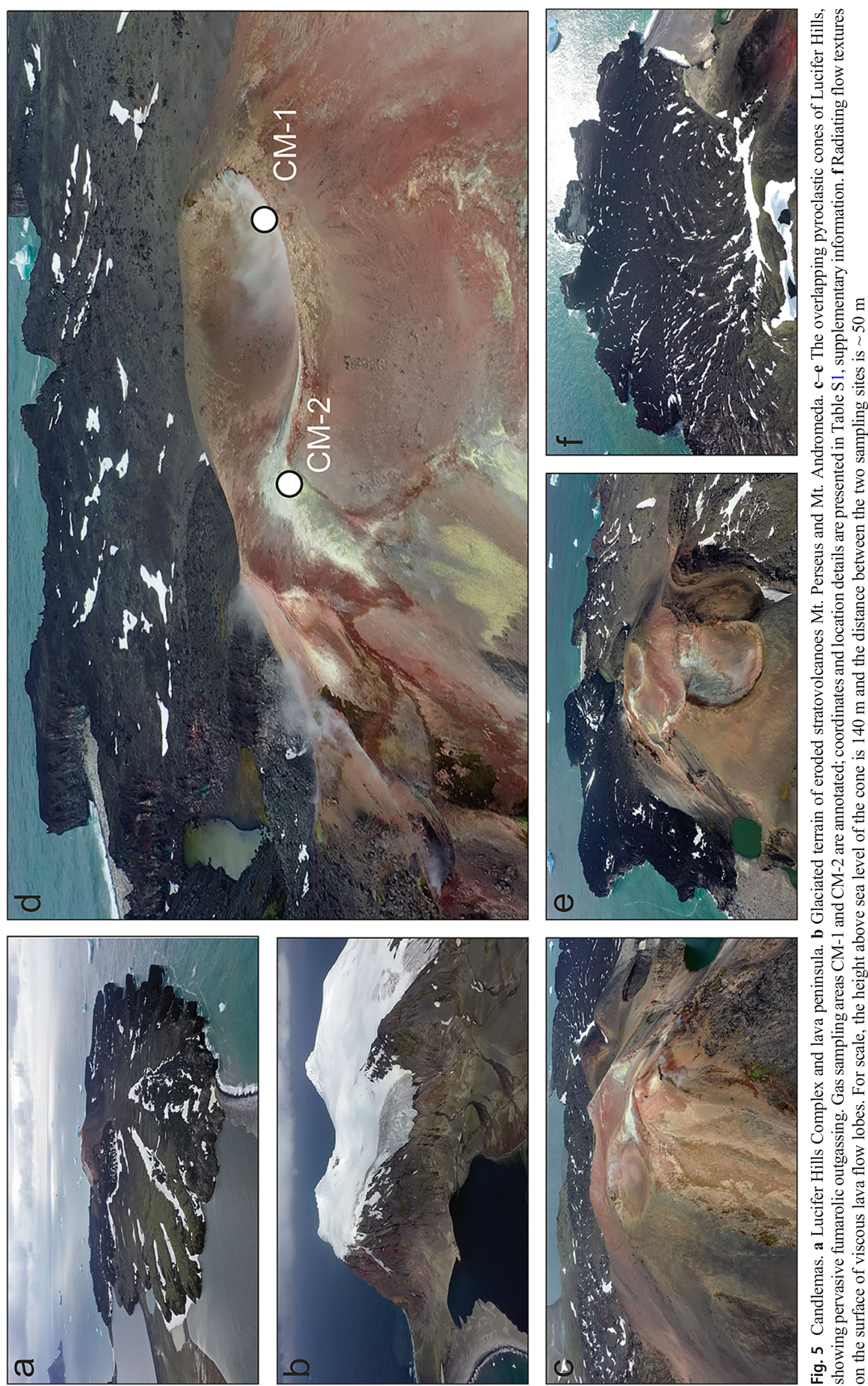

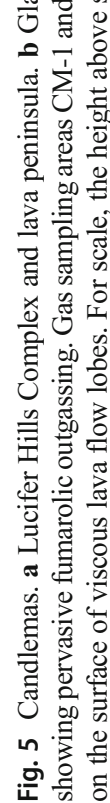



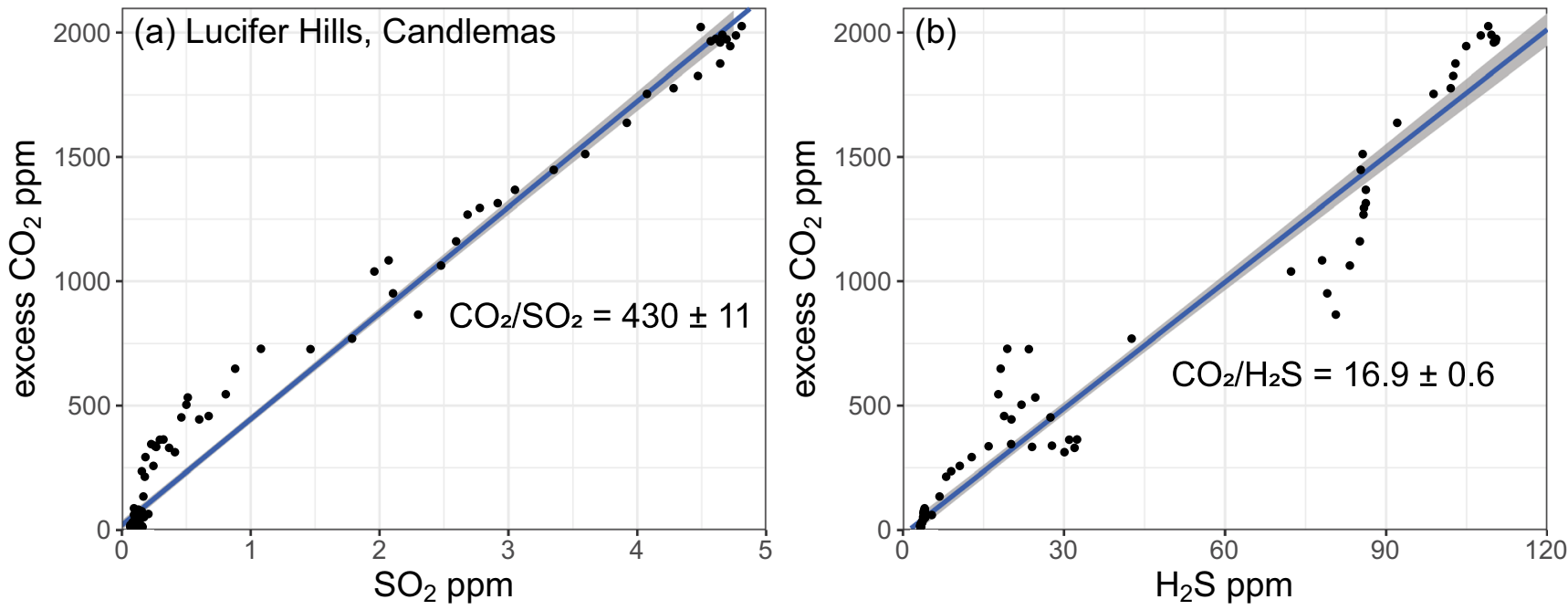

Fig. 6 Molar gas ratios sampled at the summit fumaroles at location CM-2 (see Fig. 5d) on Lucifer Hills, Candlemas. $\mathrm{CO}_{2}$ concentration is reported with atmospheric background subtracted $(418 \mathrm{ppm})$. The grey-shaded region shows the $95 \%$ confidence interval

concentrations up to $2027 \mathrm{ppm}$. Gas temperatures were not measured. We measured a $\mathrm{CO}_{2} / \mathrm{SO}_{2}$ ratio of $430 \pm 11$, equivalent to a $\mathrm{CO}_{2} / \mathrm{S}_{\mathrm{T}}$ of $16.4 \pm 3.3$ when combined with $\mathrm{H}_{2} \mathrm{~S}$. $\mathrm{H}_{2} \mathrm{O}$ was calculated for both sites based on pressure, temperature and relative humidity (see Methods; Table 1). We collected a sample of gas from fumarole site CM-1 using a preevacuated Giggenbach flask; however, the composition of this sample is identical to the composition of air (Table S3; supplementary information) - this is likely due to the low gas flux from the vent. We also note that the flask sample was collected during a blizzard, where the reduced visibility and low temperatures made the procedure very challenging.

\section{Mt. Michael and Ashen Hills, Saunders Island}

Saunders is dominated by the conical form of Mt. Michael (890 m asl; Fig. 2). There are two active vents at the summit: a main crater $\sim 500 \mathrm{~m}$ diameter and a smaller subsidiary icefilled crater to the southeast that has been visibly emitting gas since 2006 (Patrick and Smellie 2013) despite having previously been considered inactive (Holdgate and Baker 1979). The edifice is extensively glaciated and the upper flanks are heavily crevassed. The only ice-free areas are the southeastern

Table 1 Molar proportions (\%) of gas species present in fumarolic emissions. $\mathrm{S}_{\mathrm{T}}$ refers to total sulfur $\left(\mathrm{SO}_{2}+\mathrm{H}_{2} \mathrm{~S}\right)$. All gas molar ratios are presented in Table S2, supplementary information. $\mathrm{H}_{2} \mathrm{O}$ was not

\begin{tabular}{|c|c|c|c|c|c|c|c|c|}
\hline Location & ID & $\mathrm{T}\left({ }^{\circ} \mathrm{C}\right)$ & $\mathrm{H}_{2} \mathrm{O}$ & $\mathrm{CO}_{2}$ & $\mathrm{SO}_{2}$ & $\mathrm{H}_{2} \mathrm{~S}$ & $\mathrm{H}_{2}$ & $\mathrm{CO}_{2} / \mathrm{S}_{\mathrm{T}}$ \\
\hline \multirow[t]{2}{*}{ Bellingshausen } & MG-BH-1 & 99 & $88.1 \pm 23.5$ & $11.5 \pm 2.1$ & 0 & $0.3 \pm 0.05$ & $0.12 \pm 0.02$ & $38 \pm 2$ \\
\hline & MG-BH-2 & 87 & $75.4 \pm 18.9$ & $24.2 \pm 3.9$ & 0 & $0.2 \pm 0.04$ & $0.15 \pm 0.02$ & $101 \pm 6$ \\
\hline \multirow[t]{2}{*}{ Candlemas } & MG-CM-1 & 96 & $75.7 \pm 47.5$ & $25.5 \pm 9.6$ & 0 & 0 & $0.62 \pm 0.24$ & $\mathrm{n} / \mathrm{a}$ \\
\hline & MG-CM-2 & nd & $63.9 \pm 37.9$ & $29.9 \pm 9.6$ & $0.1 \pm 0.02$ & $1.8 \pm 0.57$ & $4.31 \pm 1.38$ & $16 \pm 7$ \\
\hline Mt. Michael, Saunders & MG-S-1 & ambient & & & & & & $1.8 \pm 0.2$ \\
\hline
\end{tabular}

peninsula at Nattriss Point, which includes the Ashen Hills pyroclastic cone complex, and the northeastern tip of the island where basaltic lava flows are exposed at Blackstone Plain (Fig. 2). Recurrent thermal anomalies in multi-spectral satellite imagery suggest the presence of a persistent lava lake within the crater (Fig. S1, supplementary information; Lachlan-Cope et al. 2001; Gray et al. 2019). Dual-band processing of these multi-spectral data yields temperatures of 989- $1279^{\circ} \mathrm{C}$, consistent with the expected magmatic temperatures of molten basalt among a cooler crust $\sim 200{ }^{\circ} \mathrm{C}$ (Gray et al. 2019). Reports of a strong gas plume from the summit of Mt. Michael extend back almost continuously to 1820 (LeMasurier et al. 1990). Recent activity includes persistent passive outgassing with sporadic ash-rich explosions (Patrick and Smellie 2013; Gray et al. 2019). These transient periods of explosive - presumably Strombolian - activity deposit tephra (ash and larger lapilli/bombs) over the eastern flanks of the volcano, reflecting the prevailing wind direction.

Strong and persistent gas emissions emanated from the summit of Mt. Michael during 5-8 January 2020. The plume varied from semi-transparent to condensed and could be traced downwind over the ocean for several tens of kilometres (Fig. 7a, b). On 7 January, we flew the aerial Multi-GAS

calculated for the dilute Mt. Michael plume sample. Details of all sampling sites are presented in Table S1, supplementary information. $n d$, not determined
Mt. Michael, Saunder 

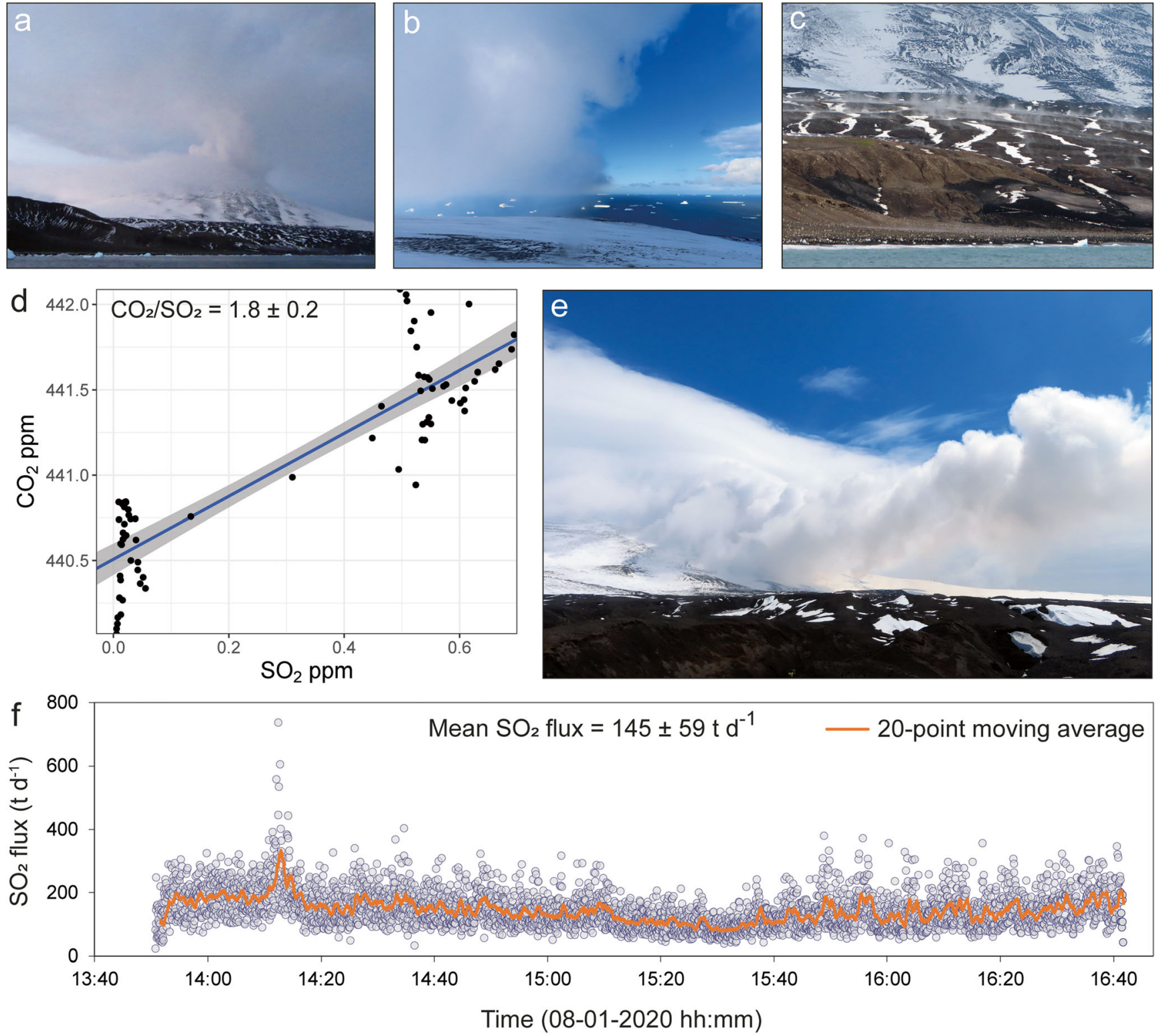

Fig. 7 Gas emissions from Mt. Michael, Saunders Island. a View from the boat of a vertically rising plume on the evening of 5 January 2020 . b Looking eastwards out to sea on 7 January 2020 shows the difference in visibility in and out of the gas plume. c Steaming ground, and a ground surface warm to touch, suggests widespread geothermal heating. $\mathbf{d ~ C O} 2-\mathrm{SO}_{2}$ scatterplot measured using aerial Multi-GAS on 7 January 2020, showing linear regression. The grey-shaded region shows the $95 \%$ confidence interval. e The condensed gas plume from Mt. Michael on 8 January 2020, showing the plume travelling at ground level down the eastern flank before lifting off. f $\mathrm{SO}_{2}$ flux time series on 8 January 2020. Flux data are calculated from UV camera $\mathrm{SO}_{2}$ absorbance images multiplied by a plume speed derived from optical flow (see Methods). For scale, the height of the snow line is $\sim 400-500 \mathrm{~m}$ above sea level

uncertainty reported is the standard error of the regression; Fig. 7d). At the dilute plume concentrations encountered $\left(<1 \mathrm{ppm} \mathrm{SO}_{2}\right.$ ) and strong eddying winds, there is considerable noise in the data that translates to uncertainty in the gas ratio. We therefore calculated the ratio based on a subsection of the total time series corresponding to the abrupt step change in gas concentrations observed when the UAS first intercepted the plume ( $n=72$, where the sampling rate is $1 \mathrm{~Hz}$ ), using a background value that represents an average of the preceding $30 \mathrm{~s}$ of measurements. We recognise that the strength of the 
correlation is not ideal and so should be interpreted with appropriate caution. $\mathrm{H}_{2} \mathrm{~S}$ was not present above the detection limit $\left(\sim 13 \%\right.$ cross-sensitivity to $\left.\mathrm{SO}_{2}\right)$ in either the aerial or ground-based measurements.

Westerly winds on 8 January caused the gas plume to fumigate the eastern flanks of the volcano, yet blizzard conditions and poor visibility prevailed at the summit. The plume travelled at ground level down the eastern flanks of Mt. Michael-resulting in a distinctive blueish haze at ground level - before lifting off over the ocean (Video S3, supplementary material). We encountered $\mathrm{SO}_{2}$ concentrations up to $2.5 \mathrm{ppm} \sim 600 \mathrm{~m}$ downwind on the upper flanks of the volcano ( $\sim 850 \mathrm{~m}$ to the east of the summit vent; Table S1): dilute, but enough to be felt in the nose and throat. $\mathrm{CO}_{2}$ concentrations during this measurement were affected by radio interference, and so, despite attempted correction using signal processing methods, the dataset was unusable. Two bag samples of gas were collected for carbon isotope measurements; these data are presented in Table S4 and described in the "Carbon isotope composition" section.

We derive an $\mathrm{SO}_{2}$ flux of $145 \pm 59[\sigma] \mathrm{t} \mathrm{day}^{-1}$ from $\sim 3 \mathrm{~h}$ of UV camera measurements acquired between 13:40 and 16:40 UTC on 8 January (Fig. 7f; data presented in Table S2 and Fig. S2, supplementary information) approximately perpendicular to the direction of plume transport (camera location annotated on Fig. 2c). Plume and ambient sunlight conditions remained relatively constant during this time interval. The condensed nature of the plume introduces additional uncertainty related to multiple scattering effects and leads us to underestimate the total flux, although we do not model this explicitly.

Stratigraphic sequences of tephra (ash and scoria lapilli) layers are preserved in the glacial ice and exposed in crevasse walls (Fig. S3, supplementary information). A layer of well-sorted coarse scoria lapilli (42 $\mathrm{cm}$ thickness) preserved in the upper parts of a crevasse was found to be laterally continuous over tens of metres, and similar but slightly thinner deposits were observed elsewhere. The upper part of this deposit has a distinctive band of red oxidation, suggesting a period of subaerial exposure before snow burial. Given the sharp lower boundary of the deposit against the underlying ice and the well-sorted nature of the clasts, we propose that this deposit is stratigraphically in situ and represents a single explosive phase of uncertain duration. Although we lack specific age constraints, given the regional snow accumulation rate, we expect this layer to have been deposited within the last 5 years. The ground surface on the eastern flank is covered by $10-30 \mathrm{~cm}$ of loose, unconsolidated ash and lapilli deposits that have likely been remobilised by wind or water. Widespread steaming ground, warm to the touch just below the surface, suggests that geothermal heating is pervasive across the island (Fig. 7c).

Ashen Hills comprises a cluster of overlapping hydromagmatic tuff cones and their associated pyroclastic deposits; the cone complex forms a striking topographic feature of the southeast peninsula of Saunders. Tuff cones (and rings) are built by explosive magma-water interaction involving the interaction of magma with either ground- or surface water (Wohletz and Sheridan 1983; Sohn and Chough 1989). Bombs of dense lava are widespread (Fig. 8d), suggesting considerable syn-eruptive fragmentation and ejection of country-rock material. The ages of the Ashen Hills eruptions are currently unconstrained, as is the geochemical relationship between the Ashen Hills magma and that erupting presently at the summit of Mt. Michael.

Fluvial run-off channels in the Ashen Hills expose sequences of stratified tephra deposits several tens of metres thick (Fig. 8). Large-scale sedimentary features include cross-stratification and undulatory bedding that resemble similar features described from "dry" base surges more generally (Waters and Fisher 1971; Sohn and Chough 1989). Base surges are turbulent, low-particle concentration density currents that are associated with explosive hydromagmatic activity and can be variably water saturated (Moore 1967; Waters and Fisher 1971; Nemeth et al. 2006). Tephra sequences comprise unconsolidated clast-supported beds of ash-coated lapilli and coarse ash alternating with laminated beds of fine to moderately coarse ash. Accretionary lapilli are common, supporting the involvement of magma-water interaction. Beds vary in thickness laterally and erode to produce characteristic circular formations, similar to those observed in eroded base surge deposits elsewhere (e.g. Hverfjall, Iceland; Liu et al. 2017). Unlike many tuff cones, the Ashen Hills deposits are not visibly palagonised.

\section{Montagu}

Montagu is a steep-sided eroded stratovolcano (Fig. 2). The structure of the summit region is dominated by a $\sim 6-\mathrm{km}$-wide ice-filled summit caldera - remnant from pre-historical explosive activity - that hosts an active intra-caldera cone, Mt. Belinda (1125 m asl). A prolonged summit eruption from Mt. Belinda began in 2001 and continued until 2007, during which eruptive activity included low-intensity explosive activity, a persistent steam/ash-plume, and several effusive events (Patrick et al. 2005; Patrick and Smellie 2013). A particularly voluminous lava flow in 2005 reached the ocean and built up a sizeable lava delta at the point of entry. Prior to this eruption, there has been no documented Holocene activity at Montagu (LeMasurier et al. 1990). Average annual $\mathrm{SO}_{2}$ emission rates, measured by satellite OMI, declined abruptly from $180 \mathrm{t}$ day ${ }^{-1}$ to $<50 \mathrm{t}_{\text {day }}{ }^{-1}$ following the end of the effusive eruption in 2007 (Carn et al. 2017). No observations were made during this expedition.

\section{Bristol}

Bristol has been one of the most frequently active subaerial volcanic centres in the SSI over the last century. Historically, volcanic activity has been focused at Mt. Sourabaya (1155 m asl; 

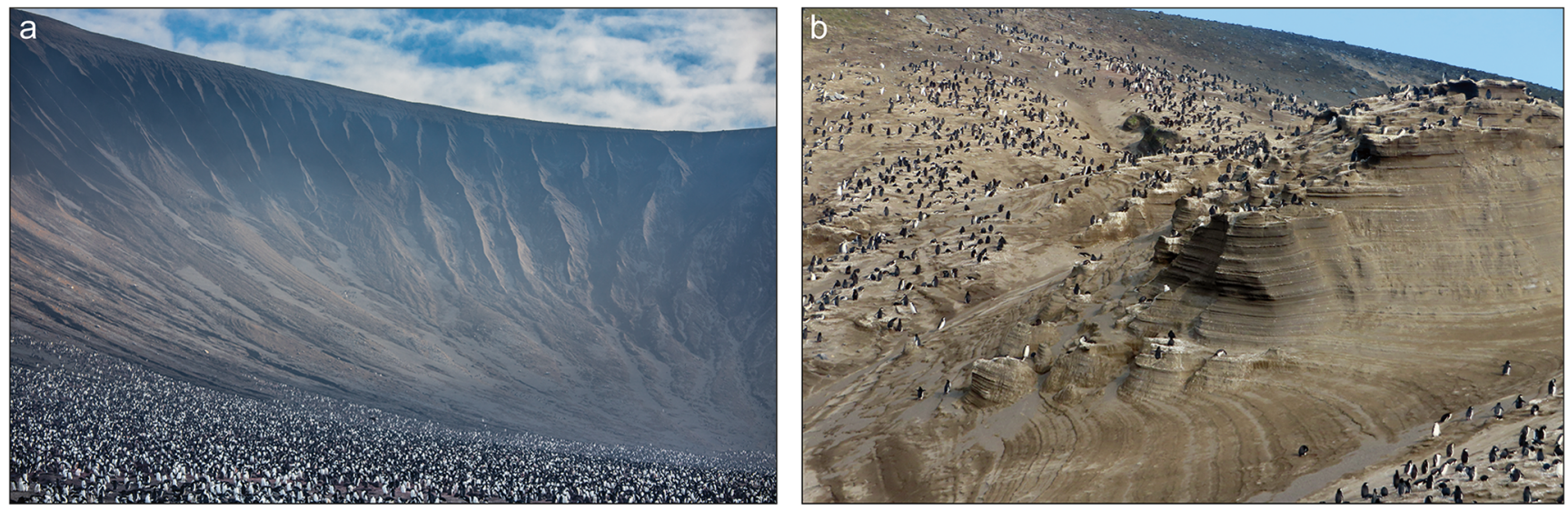
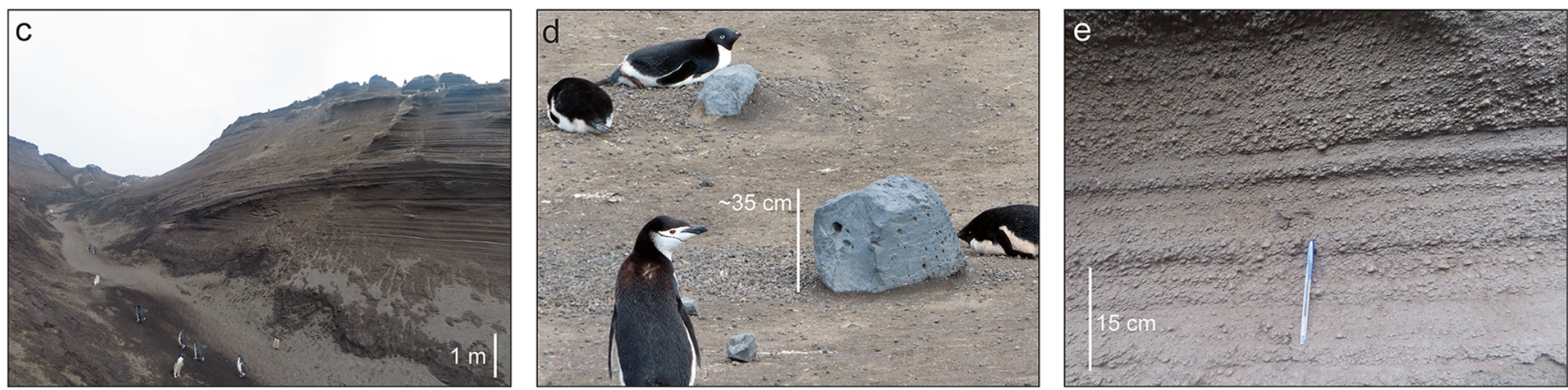

Fig. 8 Ashen Hills pyroclastic cone complex. a The pyroclastic deposits are heavily incised by fluvial erosion into regularly spaced channels. b, c Layered deposits with large-scale cross-stratification. d Dense bombs are up to metre scale are widespread; e Alternating deposits of fine ash

Fig. 2), although the highest point of the island is Mt. Darnley (1100 m asl). Eruptions are reported from 1935, 1956, 1962 (unconfirmed) and most recently April-July 2016 (Holdgate and Baker 1979; GVP, 2017b). A summit overflight in 1997 indicated that the summit of Mt. Sourabaya is built of three coalesced vents and steaming pyroclastic cones (Patrick and Smellie 2013). Two lava flows were emplaced concurrently during the 2016 eruption, alongside frequent low-intensity ash plumes from the summit cones that were visible in satellite imagery (GVP, 2017b). We did not observe any expressions of active volcanic activity or degassing as we sailed close in January 2020, although the summit was obscured.

Freezeland Rock is the largest of three small islets (inc. Grindle Rock and Wilson Rock) located on a linear trajectory immediately west of Bristol Island (Fig. S4, supplementary information). The edifice is elongated in an E-W direction and constructed from stratified pyroclastic deposits, mainly tuffs and agglomerates, crosscut by dyke structures of andesitic composition (Holdgate and Baker 1979). The three islets are considered the remnant deposits of one or more offshore volcanic centres.

\section{Southern Thule}

The islands of Bellingshausen, Cook and Thule are the subaerial exposures of a much larger submarine landform, forming coated pellets. For scale, the height of each penguin is approximately $50 \mathrm{~cm}$

collectively known as Southern Thule (Fig. 2). Thule and Cook represent the steeply eroded western and eastern flanks, respectively, of a large submerged caldera (Kemp and Nelson 1931; Smellie et al. 1998). Cook is extensively glaciated and bounded by steeply eroded cliffs. Interbedded lavas and red, oxidised scoriaceous deposits are exposed in the cliff walls, especially at Resolution Point (Fig. 9a, b). There is no record of historical volcanic activity. Thule is entirely glaciated, notably except for an ice-free peninsula at Hewison Point where pyroclastic sequences and dense lavas are exposed (Fig. 9c-e). A 1.5-2-km-wide ice-filled caldera is visible at the summit of Mt. Larsen (746 m asl), the highest point on Thule (Smellie et al. 1998). Steam was observed emanating from a small intra-caldera summit crater in 1962 (LeMasurier et al. 1990), but no emissions have been reported since (Patrick and Smellie 2013).

\section{Bellingshausen}

Bellingshausen Island is a small, simply structured, volcanic cone composed of stratified pyroclastic deposits and lava flows (Video S4, supplementary information). It is thought to be one of the youngest subaerial islands in the SSI (Holdgate and Baker 1979). The highest point of the island is on the western rim of the cone at Basilisk Peak (182 m asl; Fig. 2) and the cone laminations and lapilli beds. Lapilli are generally coated in fine ash, 

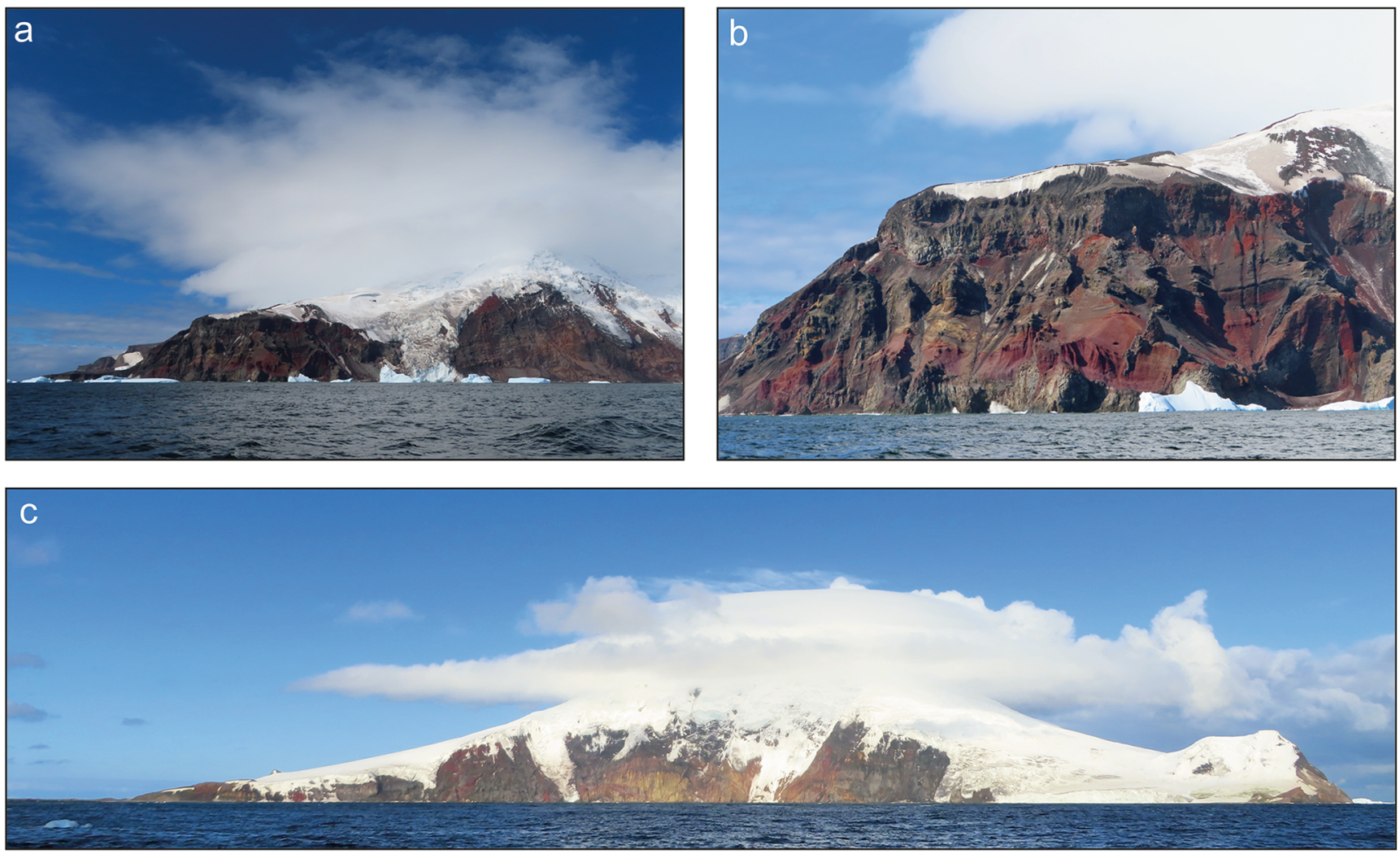

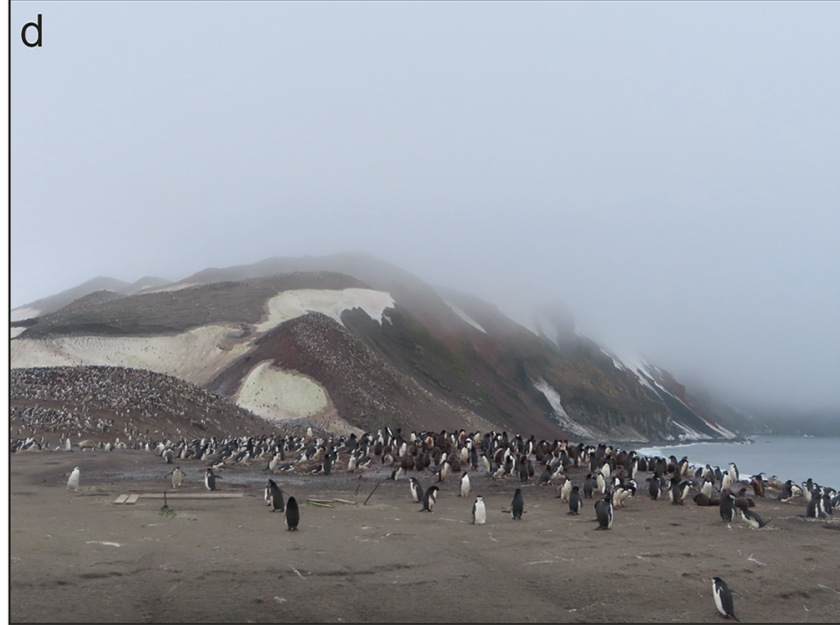

Fig. 9 Southern Thule. Cook Island: a Exposed lavas and red-oxidised pyroclastic deposits. b Resolution Point, on the northeast corner of the island, is one of the most extensive cliff exposures. Thule Island: c Overview approaching from the north. $\mathbf{d}$ View from the ice-free peninsula

tapers to a broad lava plateau to the south. The margins of the island are deeply incised by coastal erosion, exposing vertical cliffs of layered lava flow units (Fig. 10a, b). The northeast and eastern flanks of the volcanic cone are truncated by a sector collapses, exposing the internal stratigraphy (Figs. 10 and 11). A thick layer of welded agglutinate is found wherever the base of the sequence is exposed, overlain by several hundred metres of decimetre-scale massive lava flows interbedded with

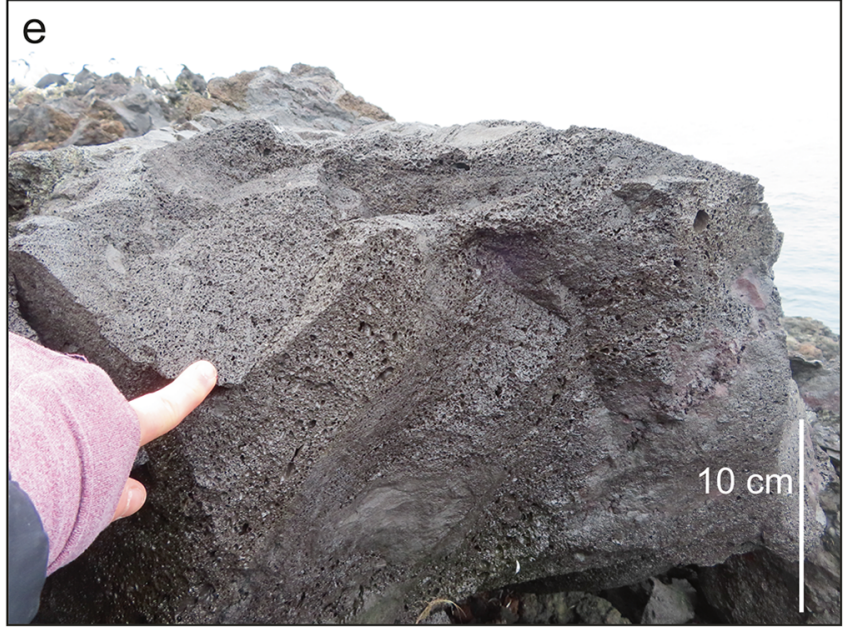

of Hewison Point towards an oxidised scoria cone on the lower flank of Mt. Larsen. e Heterogeneously vesicular lavas on Hewison Point. For scale, the height of the exposed cliffs in $\mathbf{a}-\mathbf{b}$ is several hundred metres and the height of each penguin in $\mathbf{d}$ is approximately $50 \mathrm{~cm}$

stratified pyroclastic layers of ash and scoria that dip away radially away from the cone centre in all directions and resemble fall deposits (Fig. 11). Cross-cutting discontinuities between pyroclastic units suggest multiple phases of fall deposition, each separated by periods of erosion. The sequence is capped by a dense lava flow unit.

Fumarolic outgassing inside the crater and along the seaward side of the eastern crater rim was reported by 

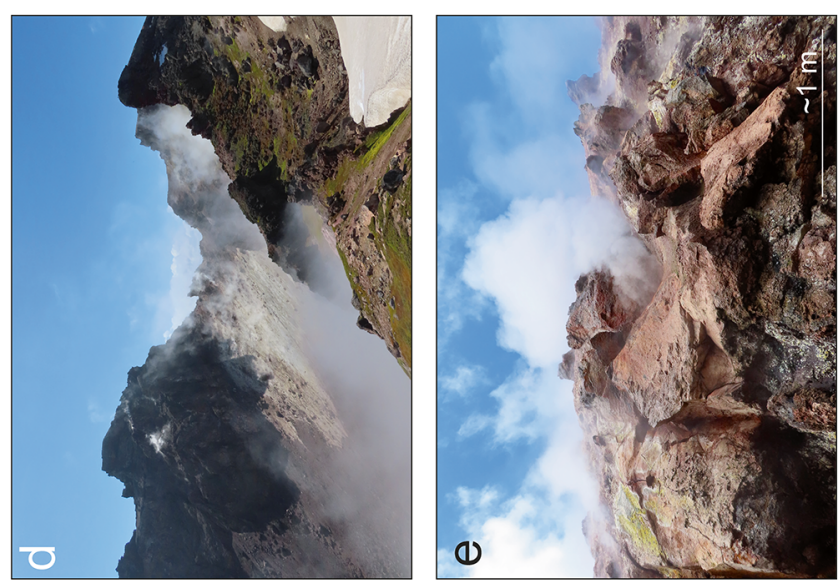

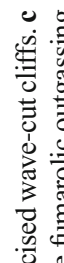

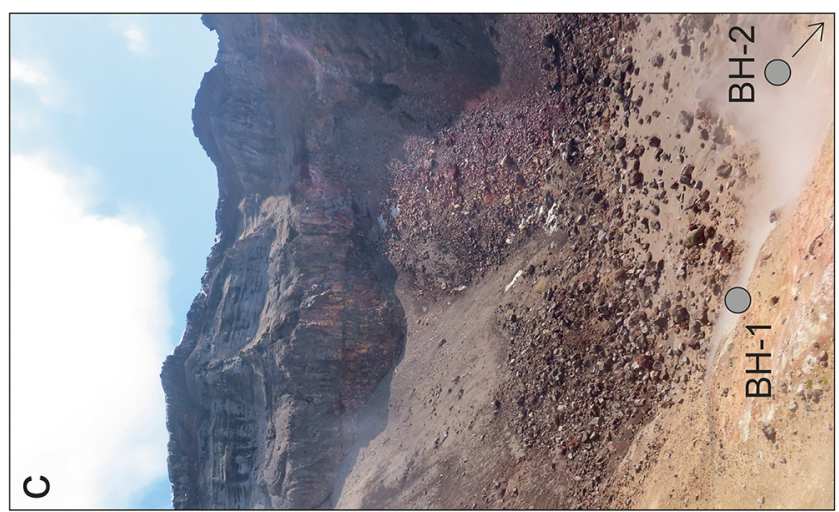

.

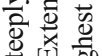

要

हี.

을

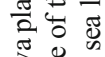

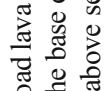

苋

도

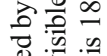

言票莙

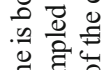

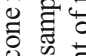

此

월

ठํ

品

至它

薦

ह ํㅕㄹ?

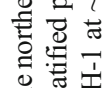

害焉

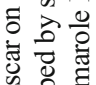
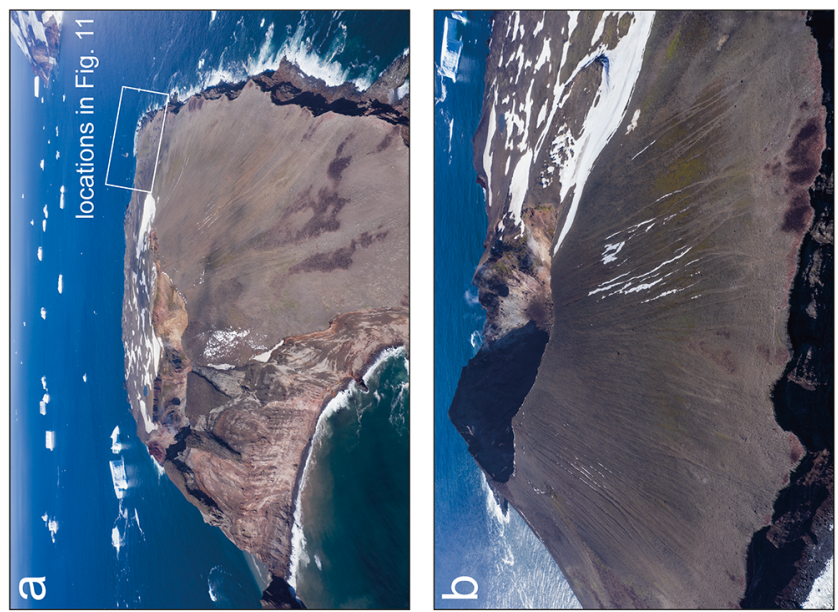

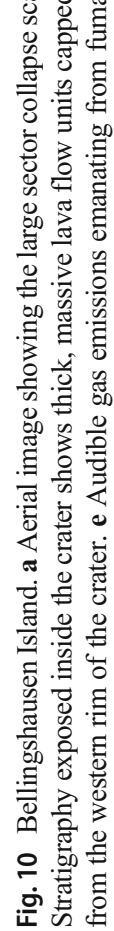



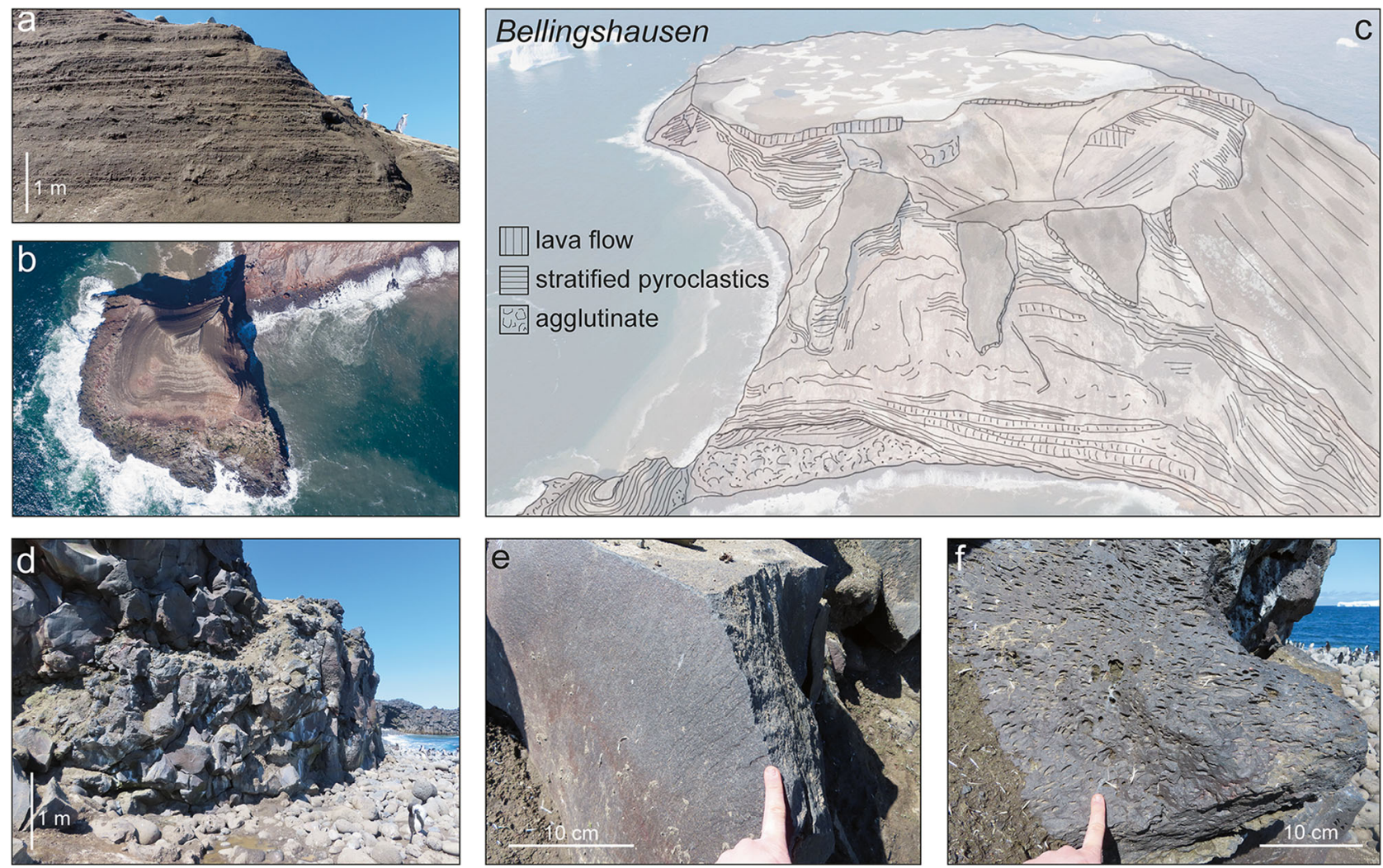

Fig. 11 Tephra deposits and lava flows, Bellingshausen Island. a Stratified pyroclastic fall deposits (ash/lapilli) on the peninsula of Hardy Point. b Jagged Point, erosion has revealed a base of welded agglutinate overlain by stratified pyroclastic deposits. c Annotated sketch

Holdgate and Baker (1979) and again in 1997, together with low-temperature thermal anomalies in satellite imagery between 2000 and 2010 (Patrick and Smellie 2013). We observed a similar distribution of emission sources from numerous fumarolic areas on the walls and base of the crater, together with ubiquitous diffuse emissions from the hydrothermally altered clay substrate. These diffuse emissions were composed only of water vapour as no measurable $\mathrm{CO}_{2}$ or sulfur species were detected by the Multi-GAS. We measured and sampled two fumaroles in the centre of the base of the crater, which contributed the densest point source emissions (partially shown in Fig. 10c; full details of the sampling sites and access requirements are presented in Table S1, supplementary information). Gas temperatures range from 96 to $98{ }^{\circ} \mathrm{C}$. The gas composition as measured by Multi-GAS is dominated by $\mathrm{H}_{2} \mathrm{O}(75-84 \mathrm{~mol} \%)$ and $\mathrm{CO}_{2}(12-24 \mathrm{~mol} \%)$, with minor $\mathrm{H}_{2} \mathrm{~S}$ $(0.2-0.3 \mathrm{~mol} \%)$ and $\mathrm{H}_{2}(<0.2 \mathrm{~mol} \%$; Table 1$)$. $\mathrm{No} \mathrm{SO}_{2}$ was present above the detection limit of $0.1 \mathrm{ppm} . \mathrm{CO}_{2}$ and $\mathrm{H}_{2} \mathrm{~S}$ exhibit a strong positive correlation $\left(r^{2}>0.99\right)$, with distinct gradients for the two different fumaroles (Fig. 12). $\mathrm{CO}_{2} / \mathrm{S}_{\mathrm{T}}$ ratios (where $\mathrm{S}_{\mathrm{T}}$ refers to total sulfur) range from $40.6 \pm 2.1$ at the strong and audibly degassing fumarole BH-1 (gas temperature $99{ }^{\circ} \mathrm{C}$; Fig. 10e) to $100.1 \pm 5.7$ in a region of more diffuse and non-audible emissions downwind from multiple distributed gas highlighting the main stratigraphic relationships. d-f Lava flow textures exposed in the basaltic andesite flows at Hardy Point. For scale, the diameter of the crater in $\mathbf{c}$ is $\sim 400 \mathrm{~m}$ and the height of the penguins in a and $\mathbf{d}$ are approximately $50 \mathrm{~cm}$

sources (fumarole BH-2), about $10 \mathrm{~m}$ away from fumarole BH-1 (Fig. 12). Two bag samples of gas were collected from fumarole BH-1 for carbon isotope measurements; these data are presented

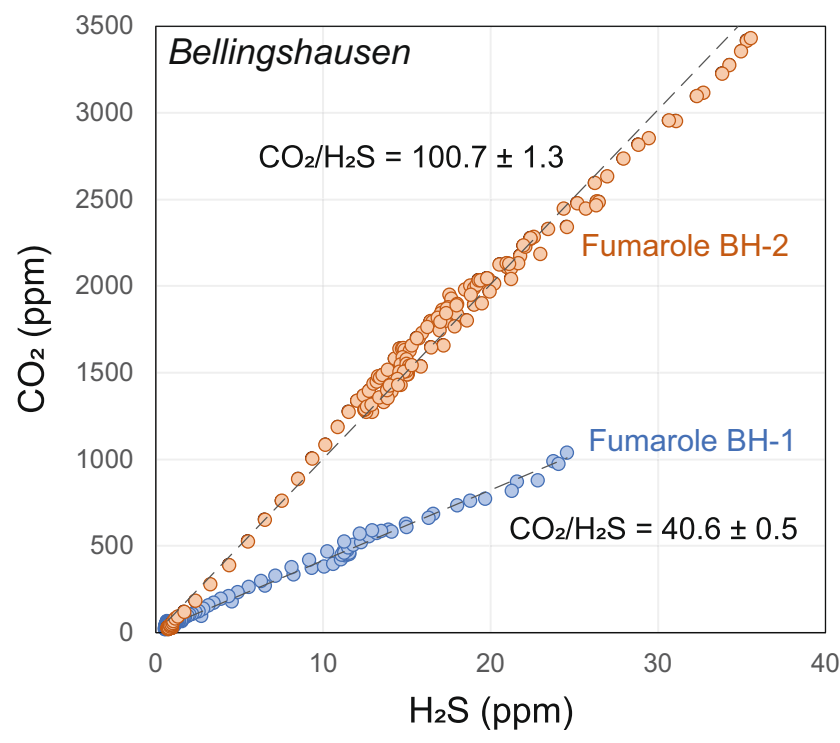

Fig. 12 Molar gas ratios from fumaroles sampled in the centre of the crater on Bellingshausen. Fumarole BH-1 is partially visible in the base of the image in Fig. 10c. $\mathrm{CO}_{2}$ concentration is reported with atmospheric background subtracted (419 ppm) 
in Table S4 and described in the "Carbon isotope composition" section.

Thick lava flow units of basaltic andesite composition (Leat et al. 2003) dominate the stratigraphy in the south of the island. Layered pyroclastic fall deposits of ash/fine lapilli are exposed on the southwest tip of the island at Hardy Point, however (Fig. 11a). Where the lava flows are exposed on the beaches at Hardy and Isaacson Points, they exhibit a bulbous, brecciated structure with curved brittle fracture surfaces (Fig. 11d-f). The interiors of the flows are moderately vesicular with elongated tear-shaped vesicles.

\section{Volcanic gas compositions $\left(\mathrm{CO}_{2} / \mathrm{S}\right)$ and $\mathrm{SO}_{2}$ flux}

Molar $\mathrm{CO}_{2} / \mathrm{S}_{\mathrm{T}}$ gas ratios from the SSVA vary between 1.8 and 101 , reflecting variable interaction of magmatic fluids with hydrothermal systems. Scrubbing of sulfur species by gasrock-water reactions under hydrothermal conditionsespecially at weak, low-temperature fumaroles $\left(<250{ }^{\circ} \mathrm{C}\right)$ produce highly variable $\mathrm{CO}_{2} / \mathrm{S}_{\mathrm{T}}$ ratios in fumarolic emissions (Giggenbach 1996; Symonds et al. 2001). Di Napoli et al. (2016) simulate the influence of scrubbing on gas chemistry at near-surface conditions, producing a model that reproduces the near-exponential decrease in $\mathrm{CO}_{2} / \mathrm{S}_{\mathrm{T}}$ with increasing temperature observed in global compilations of volcanic gas measurements (Fig. S5, supplementary information; Aiuppa et al. 2017). Low-temperature fumarolic emissions measured at Bellingshausen and Candlemas $\left(\mathrm{T} \sim 100{ }^{\circ} \mathrm{C}\right.$; Fig. S5, supplementary information) are characterised by $\mathrm{CO}_{2} / \mathrm{S}_{\mathrm{T}}$ ratios that are elevated compared to the range of values associated with high-temperature magmatic gases globally (0.2-14.7; Aiuppa et al. 2017). A difference in gas temperature from 99 (strong, audible vent) to $87^{\circ} \mathrm{C}$ (weaker emission) between two closely spaced fumaroles within Bellingshausen crater manifests as an increase in the $\mathrm{CO}_{2} / \mathrm{S}_{\mathrm{T}}$ ratio from $38 \pm 2$ to $101 \pm 6$, respectively (Table 1). Furthermore, $\mathrm{H}_{2} \mathrm{~S}$ is the dominant sulfur species in the emissions from Candlemas and Bellingshausen, with $\mathrm{SO}_{2}$ only detected one of the four fumaroles measured. $\mathrm{SO}_{2}$ is the more prevalent sulfur species in high-temperature magmatic gases, being thermodynamically favourable under oxidising conditions, reducing pressures and increasing temperatures (Gerlach and Nordlie 1975; Giggenbach 1996; Moretti and Papale 2004). Low $\mathrm{SO}_{2} / \mathrm{H}_{2} \mathrm{~S}$ ratios (i.e. a change in speciation to favour $\mathrm{H}_{2} \mathrm{~S}$ ) reflect chemical equilibration of magmatic gases with colder, more reducing hydrothermal conditions. In the context of interpreting fundamental insights in volatile sources in the SSVA, these low-temperature fumaroles provide little insight, as any magmatic signature has been long since overprinted by hydrothermal processes. Monitoring changes in the gas ratios - particularly $\mathrm{SO}_{2} / \mathrm{H}_{2} \mathrm{~S}$ - would be informative in a hazard context to identify changes in the balance of magmatic and hydrothermal contributions that may precede future phreatic or magmatic activity (e.g. Aiuppa et al.
2007, 2017; de Moor et al. 2019), but the logistical effort required to sustain such measurements in these remote sub-polarenvironments would be immense.

Mt. Michael is an open-vent volcano emitting a modest gas flux of $145 \pm 59 \mathrm{t} \mathrm{day}^{-1} \mathrm{SO}_{2}$ from a large summit crater. We measured a molar $\mathrm{CO}_{2} / \mathrm{S}_{\mathrm{T}}$ gas ratio of $1.8 \pm 0.2$ in the downwind plume, which lies close to the median arc composition of $\sim 2$ (Shinohara 2013) or 1.6 (Aiuppa et al. 2017) based on high-temperature emissions. Together with the lack of detectable $\mathrm{H}_{2} \mathrm{~S}$, this low $\mathrm{CO}_{2} / \mathrm{S}_{\mathrm{T}}$ is consistent with a magmatic gas source unmodified by hydrothermal reactions. Globally, the $\mathrm{CO}_{2} / \mathrm{S}_{\mathrm{T}}$ is well correlated with the carbon content of the subducted sediments (Aiuppa et al. 2017). Our data from Mt. Michael support predicted $\mathrm{CO}_{2} / \mathrm{S}_{\mathrm{T}}$ ratios of $\sim 1.2$ for the South Sandwich Arc based on $\mathrm{Ba} / \mathrm{La}$ trace element proxies and the carbon-poor nature of regional sediments (Plank 2005; Aiuppa et al. 2019). Considering total volatile fluxes, our calculated $\mathrm{SO}_{2}$ flux is of a similar order of magnitude to the time-averaged decadal $\mathrm{SO}_{2}$ flux of $263 \pm 63[\sigma] \mathrm{t}_{\text {day }}{ }^{-1}$ from the Ozone Monitoring Instrument (OMI) satellite measurements (2005-2015; Carn et al. 2017). Combining the $\mathrm{CO}_{2} / \mathrm{SO}_{2}$ molar ratio with our independent $\mathrm{SO}_{2}$ emission rate measured near simultaneously, we derive a $\mathrm{CO}_{2}$ flux of $179 \pm 76 \mathrm{t} \mathrm{day}^{-1}$. If our $\mathrm{CO}_{2} / \mathrm{SO}_{2}$ data are representative of the persistent outgassing behaviour of Mt. Michael, extrapolating our daily $\mathrm{CO}_{2}$ emission rate yields an annual carbon output of $65 \pm 28 \mathrm{kt} \mathrm{CO}_{2}$. However, we emphasise that we present here only a snapshot of the gas chemistry; further measurements at both Mt. Michael and Mt. Curry (Zavodovski) - the two most strongly degassing volcanoes of the SSI at present-would help to constrain both alongarc and temporal variability in gas chemistry and flux.

Although Multi-GAS and remote sensing techniques measure a smaller subset of gas species in more dilute plumes compared to a Giggenbach flask sample (arguably the most effective way to sample a "pure" gas), the ability to measure the plume composition and flux remotely proved essential during this campaign, as it does at many other volcanoes globally where high-temperature fumaroles or vent gases are inaccessible or the conditions hostile. Each technique has its merits for the study of volcanic gas chemistry, and we encourage a holistic approach wherever possible.

\section{Carbon isotope composition}

Fumarole gases and dilute plume emissions from two locations along the SSVA (the dilute summit plume from Mt. Michael, Saunders Island, and the fumarole in Bellingshausen crater) populate a linear mixing line from clean ocean air background towards that of the volcanic $\mathrm{CO}_{2}$ composition (Fig. 12; Table S4, supplementary information). All gas samples have $\mathrm{CO}_{2}$ concentrations in excess of ambient air (419 ppm) between 467 and $789 \mathrm{ppm}$, with $\delta^{13} \mathrm{C}$ values between -7.8 and 
$-11.3 \%$. Although unconstrained at higher $\mathrm{CO}_{2}$ concentrations, extrapolation of the mixing line to $100 \%$ volcanic $\mathrm{CO}_{2}$ indicates a $\delta^{13} \mathrm{C}$ composition of $-4.5 \pm 2.0 \%$ (Fig. 13, where $\delta^{13} \mathrm{C}$ is the deviation of the ratio ${ }^{13} \mathrm{C} /{ }^{12} \mathrm{C}$ relative to that of Pee Dee belemnite and the reported error is the standard error of the regression. We note that our clean ocean air background sample is isotopically light $\left(\delta^{13} \mathrm{C}=-10 \%\right.$ o) compared to the global average suggesting that it may have been fractionated to lighter values during collection. If this is the case, given that all samples were collected and stored in the same way, we assume that all would be fractionated equally. If we normalise our background to the global average $\delta^{13} \mathrm{C}=-8.5 \%$ (Fischer and Lopez 2016) and apply this offset to all samples, then the extrapolated magmatic carbon isotope composition shifts to a slightly heavier value of $-2.9 \pm 2.0 \%$.

The two sets of plume and fumarole samples were collected from different positions along the arc: Saunders in the central arc and Bellingshausen in the southern arc. That all samples populate a single linear trend (regardless of any vertical offset) suggests a common carbon source. From these data-albeit from a small sample size - we propose no fundamental along-arc variation in the carbon isotope composition along the SSVA. Variations within $4 \%$ are indistinguishable given the uncertainties of our dataset and the ambient air regression; more samples with higher concentration $\mathrm{CO}_{2}$ contents would improve these constraints.

Our best-extrapolated value of $\delta^{13} \mathrm{C}=-4.5 \pm 2.0 \%$ (or similarly the background-normalised value of $-2.9 \%$ ) lies at the upper range of the isotopic signature of the depleted upper mantle $\left(\delta^{13} \mathrm{C}=-6.5 \pm 2.5 \%\right.$; Sano and Marty 1995) and well below the signature of marine limestones

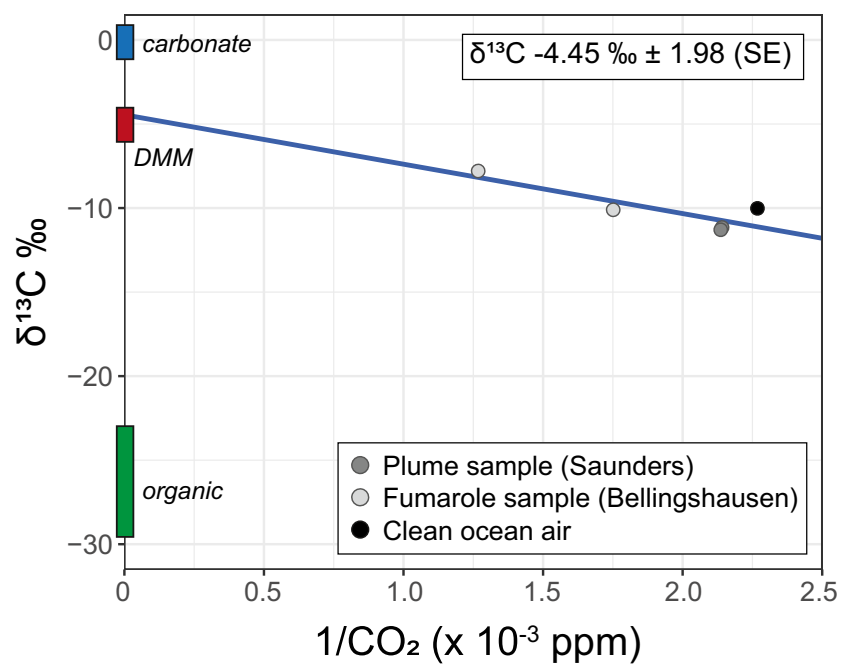

Fig. 13 Carbon isotope composition of volcanic gas emissions. Samples include fumarole gases (Bellingshausen), dilute plume emissions (Saunders) and clean ocean air background (at sea). All data points are included in the regression. The intersection of the regression line with the $y$-axis represents the magmatic carbon isotope composition extrapolated to $100 \% \mathrm{CO}_{2}$. Data presented in Table S4 (supplementary material) $\left(\delta^{13} \mathrm{C} \approx 0 \%\right.$; Fig. 13). Interpreted most simply, this result suggests that most of the emitted carbon is derived from the mantle wedge with only minor addition of a subducted component. However, Th-Sm-La trace element systematics in SSI arc lavas populate a mixing array between depleted mantle and subducted sediment end-members, indicating a variable (but non-negligible) subduction contribution; the Th-REE compositions of Saunders lavas are consistent with $\sim 50 \%$ sediment and $\sim 50 \%$ mantle, for example (Plank 2005, 2014; Fig. S6, supplementary information). In ODP 701, carbonate and organic carbon comprise $75 \%$ and $25 \%$ of the total carbon by mass, respectively, although each is distributed differently through the core. Carbonate is concentrated in the lowermost units of the core $(\sim 70 \mathrm{~m})$, with the bulk composition reaching $70-90 \% \mathrm{CaCO}_{3}$ in the basal indurated chalk. Organic carbon, in contrast, is evenly distributed at low concentrations $0.5 \mathrm{wt} \%$ throughout the section, apart from a thin carbonrich ooze at 150-m depth (Ciesielski et al. 1988). If we assign each age-specific $\delta^{13} \mathrm{C}$ signatures to these proportions of carbonate and organic carbon (from Hayes et al. 1999), we derive an approximate weighted average $\delta^{13} \mathrm{C}$ signature for the sediment pile of $-4.8 \%$ o (Table S5, supplementary information). Assuming the lithologies exposed in ODP 701 are representative of those entering the South Sandwich trench, this sedimentary carbon contribution would be indistinguishable from depleted mantle using carbon isotopes alone.

Boron isotope enrichments in SSVA lavas point to an additional subduction contribution from altered oceanic crust (Tonarini et al. 2011). Similarly, Th-Sm-La (Plank 2005) are modelled more effectively by three-component mixing between depleted mantle, sediment and altered oceanic crust (Fig. S6, supplementary information) as are other trace elements (Pearce et al. 1995). Indeed, subduction of carbonated (serpentinised) peridotite-derived either from the downgoing oceanic crust or eroded forearc - is consistent with the composition of local dredge samples and those from other slow- to ultra-slow-spreading settings globally (Lawver and Dick 1983; Vanneste and Larter 2002; Tonarini et al. 2011; Plank and Manning 2019). Globally, the carbon isotope signatures of serpentinites exposed in ophiolite sequences and at oceanic ridges are highly variable — reflecting mixing between seawater carbonate and organic carbon-with bulk $\delta^{13} \mathrm{C}$ values ranging from $-4.6 \pm 5.1 \%$ in the Northern Appenines ophiolites to $-13.7 \pm 9.6 \%$ in the Lost City hydrothermal field (Alt et al. 2013). From the data presented in this study, we cannot evaluate quantitatively the relative contributions from each of the proposed carbon sources. Rather, we intend this discussion to highlight the contrasting scenarios in which both simple and complex mixing of distinct carbon sources may generate the carbon isotopic signature observed in volcanic gas emissions and thus motivate further research into the efficiency of volatile and trace element transfer through this young arc system. 


\section{Conclusions}

We present detailed observations from an expedition to the South Sandwich Volcanic Arc in January 2020 that describe a rich and varied geological history, and we report the first in situ measurements of volcanic gas chemistry, isotopic composition and emission rate for this remote, but very active, island arc. We show that Mt. Michael on Saunders Island is a persistent gas source, releasing $145 \pm 59 \mathrm{t} \mathrm{day}^{-1}$ of $\mathrm{SO}_{2}$ and $179 \pm 76 \mathrm{t} \mathrm{day}^{-1}$ of $\mathrm{CO}_{2}$ in a plume characterised by a low $\mathrm{CO}_{2} / \mathrm{SO}_{2}$ ratio of $1.8 \pm 0.2$, consistent with the input of carbon-poor sediment to the subduction zone. Our measured $\mathrm{SO}_{2}$ flux is of a similar magnitude to that of long-term satellite observations between 2005 and 2015 (Carn et al. 2017). Temporal variability in gas chemistry is insufficiently constrained at this volcano to speculate on the longer-term carbon flux. Fumarolic outgassing is pervasive in the active centres of Candlemas and Bellingshausen, characterised by carbonrich and sulfur-poor emissions from low temperature (90$100{ }^{\circ} \mathrm{C}$ ) fumaroles. Strong steam emissions emanate from the crater of Mt. Curry, Zavodovski. Carbon isotope measurements of dilute plume and fumarole gases from along the arc suggest a magmatic $\delta^{13} \mathrm{C}$ composition of $-4.5 \pm 2.0 \%$. Considering the potential carbon sources, this carbon isotope signature suggests a dominant contribution from mantle carbon, though mixing between mantle carbon and a subduction component composed of sediment and altered crust is also permissible and more consistent with other geochemical features of South Sandwich magmas. The South Sandwich Volcanic Arc (SSVA) has huge potential for further petrological and volcanological research. It represents an ideal tectonic setting in which to explore the geochemical processes of a young, developing arc.

Supplementary Information The online version contains supplementary material available at https://doi.org/10.1007/s00445-020-01415-2.

Acknowledgements We are grateful to the crew of the Pelagic Australis - Chris Kobusch, Sophie O'Neill, Thomas Geipel-without whom this fieldwork would never have been possible. We also wish a huge thank you to all other expedition members-Paul Mayewski, Mario Potocki, Gemma Clucas, Jo Feldman, Ruth Peacey, Hamza Yassin and Ted Cheeseman - for their unwavering support in the field and for their sense of humour aboard a small boat for 5 weeks. In particular, we thank Skip Novak - expedition lead - who assisted us ashore on all our sampling excursions. E.J.L. thanks John Smellie for first putting her in contact with T.H., which ultimately led to this study. We acknowledge the support from the Government of South Georgia and the South Sandwich Islands. We thank Yuri Taran and an anonymous reviewer for their helpful reviews, and A. Cannata for editorial comments.

Authors' contributions E.J.L. and K.W. conceived the study and conducted the fieldwork; T.F. performed all carbon isotope measurements; T.P. calculated the weighted average sediment carbon isotope composition; A.A., G.G. and M.B. assembled and calibrated Multi-GAS and UV camera instruments; A.A. analysed the UV camera data; T.H coordinated the logistics that enabled the broader scientific expedition to take place, including research permits, and participated in the fieldwork. E.J.L. wrote the manuscript in discussion with all co-authors.
Funding This expedition was funded by public donations raised by Quark Expeditions Ltd., by the Government of South Georgia and the South Sandwich Islands (GSGSSI) and by individual contributions. This work was carried out under RAP 2019/025 issued by GSGSSI. EJL was supported by a Leverhulme Early Career Fellowship. A.A. and M.B. acknowledge funding from Miur (Grant N. 2017LMNLAW). K.W. acknowledges support from the Mount Everest Foundation (20-06).

Open Access This article is licensed under a Creative Commons Attribution 4.0 International License, which permits use, sharing, adaptation, distribution and reproduction in any medium or format, as long as you give appropriate credit to the original author(s) and the source, provide a link to the Creative Commons licence, and indicate if changes were made. The images or other third party material in this article are included in the article's Creative Commons licence, unless indicated otherwise in a credit line to the material. If material is not included in the article's Creative Commons licence and your intended use is not permitted by statutory regulation or exceeds the permitted use, you will need to obtain permission directly from the copyright holder. To view a copy of this licence, visit http://creativecommons.org/licenses/by/4.0/.

\section{References}

Aiuppa A, Federico C, Giudice G, Gurrieri S (2005) Chemical mapping of a fumarolic field: La Fossa Crater, Vulcano Island (Aeolian Islands, Italy). Geophys Res Lett 32. https://doi.org/10.1029/ 2005GL023207

Aiuppa A, Moretti R, Federico C, Giudice G, Gurrieri S, Liuzzo M, Papale P, Shinohara H, Valenza M (2007) Forecasting Etna eruptions by real-time observation of volcanic gas composition. Geol 35(12):1115-1118

Aiuppa A, Fischer TP, Plank T, Robidoux P, Di Napoli R (2017) Alongarc, inter-arc and arc-to-arc variations in volcanic gas $\mathrm{CO} 2 / \mathrm{ST}$ ratios reveal dual source of carbon in arc volcanism. Earth Sci Rev 168: 24 47. https://doi.org/10.1016/j.earscirev.2017.03.005

Aiuppa A, Fischer TP, Plank T, Bani P (2019) CO2 flux emissions from the Earth's most actively degassing volcanoes, 2005-2015. Sci Rep 9:5442. https://doi.org/10.1038/s41598-019-41901-y

Alt JC, Schwarzenbach EM, Früh-Green GL, Shanks WC, Bernasconi SM, Garrido CJ, Crispini L, Gaggero L, Padrón-Navarta JA, Marchesi C (2013) The role of serpentinites in cycling of carbon and sulfur: seafloor serpentinization and subduction metamorphism. Lithos 178:40-54. https://doi.org/10.1016/j.lithos.2012.12.006

Baker PE (1978) The South Sandwich Islands: iii. Petrology of the volcanic rocks. British Antarctic Survey Scientific Reports, No 93

Barker PF (1970) Plate tectonics of the Scotia Sea Region. Nature 228: 1293-1296. https://doi.org/10.1038/2281293a0

Barker PF (1995) Tectonic framework of the east Scotia Sea. In: Taylor B (ed) Backarc basins: tectonics and magmatism. Springer US, Boston, pp 281-314. https://doi.org/10.1007/978-1-4615-1843-3 7

Basile I, Petit JR, Touron S, Grousset FE, Barkov N (2001) Volcanic layers in Antarctic (Vostok) ice cores: source identification and atmospheric implications. J Geophys Res Atmos 106:31915-31931. https://doi.org/10.1029/2000JD000102

Boschen RE, Rowden AA, Clark MR, Gardner JPA (2013) Mining of deep-sea seafloor massive sulfides: a review of the deposits, their benthic communities, impacts from mining, regulatory frameworks and management strategies. Ocean Coast Manag 84:54-67. https:// doi.org/10.1016/j.ocecoaman.2013.07.005

Brett CP (1977) Seismicity of the South Sandwich Islands region. Geophys J R Astron Soc 51:453-464. https://doi.org/10.1111/j. 1365-246X.1977.tb06928.x 
Buck AL (1981) New equations for computing vapor pressure and enhancement factor. J Appl Meteorol 20:1527-1532

Calvert AJ (2011) The seismic structure of island arc crust. In: Brown D, Ryan PD (eds) Arc-continent collision, Frontiers in Earth Sciences. Springer, Berlin, pp 87-119. https://doi.org/10.1007/978-3-540$88558-04$

Campion R, Delgado-Granados H, Mori T (2015) Image-based correction of the light dilution effect for $\mathrm{SO} 2$ camera measurements. J Volcanol Geotherm Res 300:48-57

Carn S, Fioletov V, McLinden C, Li C, Krotkov N (2017) A decade of global volcanic SO 2 emissions measured from space. Sci Rep 7: 44095

Ciesielski, P.F., Kristoffersen, Y., et al., 1988. Proc. ODP, Init. Repts., 114: College Station, TX (Ocean Drilling Program). doi:https://doi. org/10.2973/odp.proc.ir.114.1988

Convey P, Smith RIL, Hodgson DA, Peat HJ (2000) The flora of the South Sandwich Islands, with particular reference to the influence of geothermal heating. J Biogeogr 27:1279-1295. https://doi.org/10. 1046/j.1365-2699.2000.00512.x

Coombs DS, Landis CA (1966) Pumice from the south sandwich eruption of march 1962 reaches New Zealand. Nature 209(5020):289-290

de Moor JM, Stix J, Avard G, Muller C, Corrales E, Diaz JA, Alan A, Brenes J, Pacheco J, Aiuppa A, Fischer TP (2019) Insights on hydrothermal-magmatic interactions and eruptive processes at Poás volcano (Costa Rica) from high-frequency gas monitoring and drone measurements. Geophys Res Lett 46:1293-1302. https://doi.org/10.1029/2018GL080301

Delle Donne D, Tamburello G, Aiuppa A, Bitetto M, Lacanna G, D’Aleo R, Ripepe M (2017) Exploring the explosive-effusive transition using permanent ultraviolet cameras. J Geophys Res Solid Earth 122:4377-4394. https://doi.org/10.1002/2017JB014027

Delle Donne D, Aiuppa A, Bitetto M, D'Aleo R, Coltelli M, Coppola D, Pecora E, Ripepe M, Tamburello G (2019) Changes in SO2 flux regime at Mt. Etna captured by automatically processed ultraviolet camera data. Remote Sens 11:1201. https://doi.org/10.3390/ rs11101201

Derrien A, Richter N, Meschede M, Walter T (2019) Optical DSLR camera- and UAV footage of the remote Mount Michael Volcano, Saunders Island (South Sandwich Islands), acquired in May 2019. GFZ Data Serv. https://doi.org/10.5880/GFZ.2.1.2019.003

Di Napoli R, Aiuppa A, Bergsson B, Ilyinskaya E, Pfeffer MA, Guðjónsdóttir SR, Valenza M (2016) Reaction path models of magmatic gas scrubbing. Chem Geol 420:251-269. https://doi.org/10. 1016/j.chemgeo.2015.11.024

Farquharson JI, James MR, Tuffen H (2015) Examining rhyolite lava flow dynamics through photo-based 3D reconstructions of the 2011-2012 lava flowfield at Cordón-Caulle, Chile. J Volcanol Geotherm Res 304:336-348. https://doi.org/10.1016/j.jvolgeores. 2015.09.004

Fink J (1980) Surface folding and viscosity of rhyolite flows. Geology 8: 250-254. https://doi.org/10.1130/0091-7613(1980)8<250: SFAVOR $>2.0 . \mathrm{CO} ; 2$

Fischer TP, Lopez TM (2016) First airborne samples of a volcanic plume for $813 \mathrm{C}$ of $\mathrm{CO} 2$ determinations. Geophys Res Lett 43:3272-3279

Fischer TP, Arellano S, Carn S, Aiuppa A, Galle B, Allard P, Lopez T, Shinohara H, Kelly P, Werner C, Cardellini C (2019) The emissions of $\mathrm{CO}_{2}$ and other volatiles from the world's subaerial volcanoes. Sci Rep 9(1):1-11

Garabato AC, Heywood KJ, Stevens DP (2002) Modification and pathways of southern ocean deep waters in the Scotia Sea. Deep-Sea Res I Oceanogr Res Pap 49:681-705. https://doi.org/10.1016/S09670637(01)00071-1

Gass IG, Harris PG, Holdgate MW (1963) Pumice eruption in the area of the South Sandwich Islands. Geol Mag 100:321-330. https://doi. org/10.1017/S0016756800056053
Gerlach TM, Nordlie BE (1975) The C-O-H-S gaseous system; part I, composition limits and trends in basaltic cases. Am J Sci 275:353376. https://doi.org/10.2475/ajs.275.4.353

Giggenbach WF (1996) Chemical composition of volcanic gases. In: Scarpa R, Tilling RI (eds) Monitoring and mitigation of volcano hazards. Springer, Berlin, Heidelberg, pp 221-256. https://doi.org/ 10.1007/978-3-642-80087-0_7

Giner-Robles JL, Pérez-López R, Rodríguez-Pascua MA, Martínez-Díaz JJ, González-Casado JM (2009) Present-day strain field on the South American slab underneath the Sandwich Plate (Southern Atlantic Ocean): a kinematic model. Geol Soc Lond, Spec Publ 328:155-167. https://doi.org/10.1144/SP328.6

Global Volcanism Program (2017a) Report on Zavodovski (United Kingdom). In: Crafford AE, Venzke E (eds) Bulletin of the Global Volcanism Network, vol 42. Smithsonian Institution, p 2. https:// doi.org/10.5479/si.GVP.BGVN201702-390130

Global Volcanism Program (2017b) Report on Bristol Island (United Kingdom). In: Crafford AE, Venzke E (eds) Bulletin of the Global Volcanism Network, vol 42. Smithsonian Institution, p 9. https:// doi.org/10.5479/si.GVP.BGVN201709-390080

Gray DM, Burton-Johnson A, Fretwell PT (2019) Evidence for a lava lake on Mt. Michael volcano, Saunders Island (South Sandwich Islands) from Landsat, Sentinel-2 and ASTER satellite imagery. J Volcanol Geotherm Res 379:60-71. https://doi.org/10.1016/j. jvolgeores.2019.05.002

Hart T, Convey P (2018) The South Sandwich Islands - a community of meta-populations across all trophic levels. Biodiversity 19:20-33. https://doi.org/10.1080/14888386.2018.1464952

Hayes JM, Strauss H, Kaufman AJ (1999) The abundance of 13C in marine organic matter and isotopic fractionation in the global biogeochemical cycle of carbon during the past $800 \mathrm{Ma}$. Chem Geol 161:103-125. https://doi.org/10.1016/S0009-2541(99)00083-2

Holdgate, Baker (1979) The South Sandwich Islands: I. General description, vol 91. British Antarctic Survey Scientific Reports, No. 91

Ilanko T, Fischer TP, Kyle P, Curtis A, Lee H, Sano Y (2019) Modification of fumarolic gases by the ice-covered edifice of Erebus volcano, Antarctica. J Volcanol Geotherm Res 381:119139. https://doi.org/10.1016/j.jvolgeores.2019.05.017

Kemp, Nelson (1931) The South Sandwich Islands. 'Discovery' Reports, vol 3, pp 133-198

Kern C, Lübcke P, Bobrowski N, Campion R, Mori T, Smekens J-F, Stebel K, Tamburello G, Burton M, Platt U, Prata F (2015) Intercomparison of $\mathrm{SO} 2$ camera systems for imaging volcanic gas plumes. J Volcanol Geotherm Res 300:22-36. https://doi.org/10. 1016/j.jvolgeores.2014.08.026

Lachlan-Cope T, Smellie JL, Ladkin R (2001) Discovery of a recurrent lava lake on Saunders Island (South Sandwich Islands) using AVHRR imagery. J Volcanol Geotherm Res 112:105-116. https:// doi.org/10.1016/S0377-0273(01)00237-2

Lamur A, Lavallée Y, Iddon FE, Hornby AJ, Kendrick JE, von Aulock FW, Wadsworth FB (2018) Disclosing the temperature of columnar jointing in lavas. Nat Commun 9:1432. https://doi.org/10.1038/ s41467-018-03842-4

Larter RD, Vanneste LE, Morris P, Smythe DK (2003) Structure and tectonic evolution of the South Sandwich arc. Geol Soc Lond, Spec Publ 219:255-284. https://doi.org/10.1144/GSL.SP.2003. 219.01.13

Lawver LA, Dick HJB (1983) The American-Antarctic Ridge. J Geophys Res Solid Earth 88:8193-8202. https://doi.org/10.1029/ JB088iB10p08193

Leat PT, Smellie JL, Millar IL, Larter RD (2003) Magmatism in the South Sandwich arc. Geol Soc Lond, Spec Publ 219:285-313. https://doi. org/10.1144/GSL.SP.2003.219.01.14

Leat PT, Pearce JA, Barker PF, Millar IL, Barry TL, Larter RD (2004) Magma genesis and mantle flow at a subducting slab edge: the 
South Sandwich arc-basin system. Earth Planet Sci Lett 227:17-35. https://doi.org/10.1016/j.epsl.2004.08.016

Leat PT, Tate AJ, Tappin DR, Day SJ, Owen MJ (2010) Growth and mass wasting of volcanic centers in the northern South Sandwich arc, South Atlantic, revealed by new multibeam mapping. Mar Geol 275:110-126. https://doi.org/10.1016/j.margeo.2010.05.001

Leat PT, Day SJ, Tate AJ, Martin TJ, Owen MJ, Tappin DR (2013) Volcanic evolution of the South Sandwich Volcanic Arc, South Atlantic, from multibeam bathymetry. J Volcanol Geotherm Res 265:60-77. https://doi.org/10.1016/j.jvolgeores.2013.08.013

Leat PT, Fretwell PT, Tate AJ, Larter RD, Martin TJ, Smellie JL, Jokat W, Bohrmann G (2016) Bathymetry and geological setting of the South Sandwich Islands volcanic arc. Antarct Sci 28:293-303. https://doi.org/10.1017/S0954102016000043

LeMasurier WE, Thomson JW, Baker PE, Kyle PR, Rowley PD, Smellie JL, Verwoerd WJ (1990) Volcanoes of the Antarctic Plate and Southern Ocean. American Geophysical Union, Washington, D.C.

Li Y, Liu J (2020) Late Cenozoic columnar-jointed basaltic lavas in eastern and southeastern China: morphologies, structures, and formation mechanisms. Bull Volcanol 82(7):1-23. https://doi.org/10. 1007/s00445-020-01397-1

Linse K, Copley JT, Connelly DP, Larter R, Pearce DA, Polunin NVC, Rogers AD, Chen C, Clarke A, Glover AG, Graham AGC, Huvenne VAI, Marsh L, Reid WDK, Roterman CN, Sweeting CJ, Zwirglmaier K, Tyler PA (2019) Fauna of the Kemp Caldera and its upper bathyal hydrothermal vents (South Sandwich Arc, Antarctica). R Soc Open Sci 6:191501

Liu EJ, Cashman KV, Rust AC, Höskuldsson A (2017) Contrasting mechanisms of magma fragmentation during coeval magmatic and hydromagmatic activity: the Hverfjall Fires fissure eruption, Iceland. Bull Volcanol 79:68. https://doi.org/10.1007/s00445-017-1150-8

Liu EJ, Wood K, Mason E, Edmonds M, Aiuppa A, Giudice G, Bitetto M, Francofonte V, Burrow S, Richardson T, Watson M (2019) Dynamics of outgassing and plume transport revealed by proximal Unmanned Aerial System (UAS) measurements at Volcán Villarrica, Chile. Geochem Geophys Geosyst 20(2):730-750

Livermore R, Cunningham A, Vanneste L, Larter R (1997) Subduction influence on magma supply at the East Scotia Ridge. Earth Planet Sci Lett 150:261-275. https://doi.org/10.1016/S0012-821X(97)00074-5

Lucas BD, Kanade T (1981) An iterative image registration technique with an application to stereo vision. In: Proceedings DARPA Image Understanding Workshop, pp 121-130

Lynch HJ, White R, Naveen R, Black A, Meixler MS, Fagan WF (2016) In stark contrast to widespread declines along the Scotia Arc, a survey of the South Sandwich Islands finds a robust seabird community. Polar Biol 39:1615-1625. https://doi.org/10.1007/s00300015-1886-6

Marine Protected Areas Order (2013) S. R. \& O. No: 1 of 2013

Marine Protected Areas Order (2019) S. R. \& O. No: 1 of 2019

Moore JG (1967) Base surge in recent volcanic eruptions. Bull Volcanol 30:337-363. https://doi.org/10.1007/BF02597678

Moretti R, Papale P (2004) On the oxidation state and volatile behavior in multicomponent gas-melt equilibria. Chem Geol, 7th Silicate Melt Workshop 213:265-280. https://doi.org/10.1016/j.chemgeo.2004.08.048

Müller C (2001) Upper mantle seismic anisotropy beneath Antarctica and the Scotia Sea region. Geophys J Int 147:105-122. https://doi.org/ 10.1046/j.1365-246X.2001.00517.x

Müller C, Bayer B, Eckstaller A, Miller H (2008) Mantle flow in the South Sandwich subduction environment from source-side shear wave splitting. Geophys Res Lett 35. https://doi.org/10.1029/ 2007GL032411

Németh K, Cronin SJ, Charley D, Harrison M, Garae E (2006) Exploding lakes in Vanuatu - "Surtseyan-style" eruptions witnessed on Ambae Island. Episodes 29(2):87-92. https://doi.org/10.18814/epiiugs/ 2006/v29i2/002
Ninkovich D, Heezen BC, Conolly JR, Burckle LH (1964) South Sandwich tephra in deep-sea sediments. Deep-Sea Res Oceanogr Abstr 11:605-619. https://doi.org/10.1016/0011-7471(64)90005-1

Patrick MR, Smellie JL (2013) Synthesis A spaceborne inventory of volcanic activity in Antarctica and southern oceans, 2000-10. Antarct Sci 25:475-500. https://doi.org/10.1017/ S0954102013000436

Patrick MR, Smellie JL, Harris AJL, Wright R, Dean K, Izbekov P, Garbeil H, Pilger E (2005) First recorded eruption of Mount Belinda volcano (Montagu Island), South Sandwich Islands. Bull Volcanol 67:415-422. https://doi.org/10.1007/s00445-004-0382-6

Pearce JA, Baker PE, Harvey PK, Luff IW (1995) Geochemical evidence for subduction fluxes, mantle melting and fractional crystallization beneath the South Sandwich Island Arc. J Petrol 36:1073-1109. https://doi.org/10.1093/petrology/36.4.1073

Pearce JA, Barker PF, Edwards SJ, Parkinson IJ, Leat PT (2000) Geochemistry and tectonic significance of peridotites from the South Sandwich arc-basin system, South Atlantic. Contrib Mineral Petrol 139:36-53. https://doi.org/10.1007/s004100050572

Pering TD, Liu EJ, Wood K, Wilkes TC, Aiuppa A, Tamburello G, Bitetto M, Richardson T, McGonigle AJS (2020) Combined ground and aerial measurements resolve vent-specific gas fluxes from a multi-vent volcano. Nat Commun 11(1):1-11

Phillips JC, Humphreys MCS, Daniels KA, Brown RJ, Witham F (2013) The formation of columnar joints produced by cooling in basalt at Staffa, Scotland. Bull Volcanol 75:715. https://doi.org/10.1007/ s00445-013-0715-4

Plank T (2005) Constraints from thorium/lanthanum on sediment recycling at subduction zones and the evolution of the continents. J Petrol 46:921-944. https://doi.org/10.1093/petrology/egi005

Plank T (2014) The chemical composition of subducting sediments. In: Keeling RF (ed) Treatise on geochemistry. Elsevier, Amsterdam, pp 607-629

Plank T, Langmuir CH (1998) The chemical composition of subducting sediment and its consequences for the crust and mantle. Chem Geol 145:325-394. https://doi.org/10.1016/S0009-2541(97)00150-2

Plank T, Manning CE (2019) Subducting carbon. Nature 574:343-352. https://doi.org/10.1038/s41586-019-1643-z

Reynolds RW (1996) Volcanic hazards at Sierra Negra. Noticias de Galápagos 57:13-19

Roberts SJ, Monien P, Foster LC, Loftfield J, Hocking EP, Schnetger B, Pearson EJ, Juggins S, Fretwell P, Ireland L, Ochyra R, Haworth AR, Allen CS, Moreton SG, Davies SJ, Brumsack H-J, Bentley MJ, Hodgson DA (2017) Past penguin colony responses to explosive volcanism on the Antarctic Peninsula. Nat Commun 8:14914. https://doi.org/10.1038/ncomms14914

Sano Y, Marty B (1995) Origin of carbon in fumarolic gas from island arcs. Chem Geol 119:265-274. https://doi.org/10.1016/00092541(94)00097-R

Shinohara H (2005) A new technique to estimate volcanic gas composition: plume measurements with a portable multi-sensor system. J Volcanol Geotherm Res 143:319-333. https://doi.org/10.1016/j. jvolgeores.2004.12.004

Shinohara H (2013) Composition of volcanic gases emitted during repeating Vulcanian eruption stage of Shinmoedake, Kirishima volcano, Japan. Earth Planets Space 65:17

Smalley R, Dalziel IWD, Bevis MG, Kendrick E, Stamps DS, King EC, Taylor FW, Lauría E, Zakrajsek A, Parra H (2007) Scotia arc kinematics from GPS geodesy. Geophys Res Lett 34. https://doi.org/10. 1029/2007GL031699

Smellie JL (1999) The upper Cenozoic tephra record in the south polar region: a review. Glob Planet Chang 21:51-70. https://doi.org/10. 1016/S0921-8181(99)00007-7

Smellie JL, Morris P, Leat PT, Turner DB, Houghton D (1998) Submarine caldera and other volcanic observations in Southern 
Thule, South Sandwich Islands. Antarct Sci 10:171-172. https://doi. org/10.1017/S0954102098000224

Sohn YK, Chough SK (1989) Depositional processes of the Suwolbong tuff ring, Cheju Island (Korea). Sedimentology 36:837-855. https:// doi.org/10.1111/j.1365-3091.1989.tb01749.x

Spry A (1962) The origin of columnar jointing, particularly in basalt flows. J Geol Soc Aust 8:191-216. https://doi.org/10.1080/ 14400956208527873

Symonds RB, Gerlach TM, Reed MH (2001) Magmatic gas scrubbing: implications for volcano monitoring. J Volcanol Geotherm Res 108: 303-341. https://doi.org/10.1016/S0377-0273(00)00292-4

Tamburello G (2015) Ratiocalc: software for processing data from multicomponent volcanic gas analyzers. Comput Geosci 82:63-67. https://doi.org/10.1016/j.cageo.2015.05.004

Thomas C, Livermore R, Pollitz F (2003) Motion of the Scotia Sea plates. Geophys J Int 155:789-804. https://doi.org/10.1111/j.1365-246X. 2003.02069.x
Tonarini S, Leeman WP, Leat PT (2011) Subduction erosion of forearc mantle wedge implicated in the genesis of the South Sandwich Island (SSI) arc: evidence from boron isotope systematics. Earth Planet Sci Lett 301:275-284. https://doi.org/10.1016/j.epsl.2010.11.008

Vanneste LE, Larter RD (2002) Sediment subduction, subduction erosion, and strain regime in the northern South Sandwich forearc: northern South Sandwich Forearc. J Geophys Res 107:EPM 5-1EPM 5-24. https://doi.org/10.1029/2001JB000396

Vervoort JD, Plank T, Prytulak J (2011) The Hf-Nd isotopic composition of marine sediments. Geochim Cosmochim Acta 75:5903-5926. https://doi.org/10.1016/j.gca.2011.07.046

Waters AC, Fisher RV (1971) Base surges and their deposits: Capelinhos and Taal volcanoes. J Geophys Res Solid Earth:5596-5614. https://doi.org/ 10.1029/JB076i023p05596@10.1002/(ISSN)2169-9356.METIV1

Wohletz KH, Sheridan MF (1983) Hydrovolcanic explosions; II, evolution of basaltic tuff rings and tuff cones. Am J Sci 283:385-413. https://doi.org/10.2475/ajs.283.5.385 